\title{
Iodine-129 in Soils from Northern Ukraine and the Retrospective Dosimetry of the Iodine-131 Exposure after the Chernobyl Accident
}

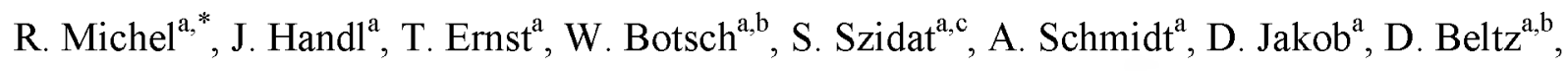 \\ L.D. Romantschuk ${ }^{\mathrm{d}}$, H.-A. Synal ${ }^{\mathrm{e}}$, C. Schnabel ${ }^{\mathrm{a}, \mathrm{f,g}}$, J.M. López-Gutiérrez $^{\mathrm{h}}$
}

a Zentrum für Strahlenschutz und Radioökologie (ZSR), Universität Hannover, Herrenhaeuser Str. 2, D-30419 Hannover, Germany

b TÜV Hannover/Sachsen-Anhalt e.V., Am TÜV 1, 30519 Hannover, Germany

c Labor für Radio- und Umweltchemie, Universität Bern, Freiestr. 3, CH-3012 Bern, Switzerland

d State University of Agriculture and Ecology, Stari Bulvar 7, Zhitomir, 262001 Ukraine

e Paul Scherrer Institut (PSI), c/o Institut für Teilchenphysik, ETH Hönggerberg, CH-8093 Zürich, Switzerland

f Institut für Teilchenphysik, ETH Hönggerberg, CH-8093 Zürich, Switzerland

g Scottish Universities Environmental Research Centre, Scottish Enterprise Technology Park, East Kilbride G75 0QF, UK

h Dpto. de Física Atómica, Molecular y Nuclear, Universidad de Sevilla, Apdo. 1065, E-41080 Sevilla, Spain

* Corresponding author: Fax: ++49-511-762 3319, e-mail address: michel@zsr.uni-hannover.de

\section{The Science of the Total Environment (2004) accepted for publication}

Keywords: iodine-129, iodine-131, accelerator mass spectrometry, radiochemical neutron activation analysis, retrospective dosimetry, radionuclide migration 


\section{ABSTRACT}

Forty-eight soil profiles down to a depth of $40 \mathrm{~cm}$ were taken in Russia and Ukraine in 1995 and 1997, respectively, in order to investigate the feasibility of retrospective dosimetry of the ${ }^{131}$ I exposure after the Chernobyl accident via the long-lived ${ }^{129}$ I. The sampling sites covered areas almost not affected by fallout from the Chernobyl accident such as Moscow/Russia and the Zhitomir district in Ukraine as well as the highly contaminated Korosten and Narodici districts in Ukraine. ${ }^{129}$ I was analyzed by radiochemical neutron activation analysis (RNAA) and accelerator mass spectrometry (AMS). ${ }^{127}$ I was measured for some profiles by RNAA or ion chromatography. The results for ${ }^{127} \mathrm{I}$ demonstrated large differences in the capabilities of the soils to store iodine over long time-spans. The depth profiles of ${ }^{129} \mathrm{I}$ and of ${ }^{137} \mathrm{Cs}$ showed large differences in the migration behavior between the two nuclides but also for each nuclide among the different sampling sites. Though it cannot be quantified how much ${ }^{129} \mathrm{I}$ and ${ }^{137} \mathrm{Cs}$ was lost out of the soil columns into deeper depths, the inventories in the columns were taken as proxies for the total inventories. For ${ }^{129}$ I, these inventories were at least three orders of magnitude higher than a pre-nuclear value of $0.084 \pm 0.017 \mathrm{mBq} \mathrm{m}^{-2} \mathrm{de}-$ rived from a soil profile taken in 1939 in Lutovinovo/Russia. From the samples from Moscow and Zhitomir a pre-Chernobyl ${ }^{129}$ I inventory of $(44 \pm 24) \mathrm{mBq} \mathrm{m}^{-2}$ was determined, limiting the feasibility of ${ }^{129} \mathrm{I}$ retrospective dosimetry to areas where the ${ }^{129} \mathrm{I}$ inventories exceed $100 \mathrm{mBq} \mathrm{m}^{-2}$. Higher average ${ }^{129} \mathrm{I}$ inventories in the Korosten and Narodici districts of $130 \mathrm{mBq} \mathrm{m}^{-2}$ and $848 \mathrm{mBq} \mathrm{m}^{-2}$, respectively, allowed determination of the ${ }^{129}$ I fallout due to the Chernobyl accident. Based on the total ${ }^{129} \mathrm{I}$ inventories and on literature data for the atomic ratio of ${ }^{129} \mathrm{I} /{ }^{131} \mathrm{I}=13.6 \pm 2.8$ for the Chernobyl emissions and on aggregated dose coefficients for ${ }^{131} \mathrm{I}$, the thyroid exposure due to ${ }^{131} \mathrm{I}$ after the Chernobyl accident was estimated for the inhabitants of 4 villages in the Korosten and of 3 villages in the Narodici districts. The limitations and uncertainties of the ${ }^{129}$ I retrospective dosimetry are discussed. 


\section{Introduction}

The long-lived radionuclide ${ }^{129} \mathrm{I}\left(T_{1 / 2}=15.7 \mathrm{Ma}, E_{\beta, \max }=0.2 \mathrm{MeV}, E_{\gamma}=39.58 \mathrm{keV}, I_{\gamma}=0.0752\right)$ is produced in nature by cosmic-ray induced spallation of xenon in the atmosphere and by spontaneous fission in the geosphere. The total natural inventory of ${ }^{129} \mathrm{I}$ in the lithosphere was estimated to be $50000 \mathrm{~kg}(327 \mathrm{TBq})$ and of this only $263 \mathrm{~kg}(1.7 \mathrm{TBq})$ was estimated to be available as "free" inventory of atmosphere, hydrosphere and biosphere and mixing with the stable ${ }^{127} \mathrm{I}$; see Schmidt et al. (1998) for details. The natural abundances of ${ }^{129} \mathrm{I}$ have been globally and in a sustainable way changed by ${ }^{129} \mathrm{I}$ released by man into the environment. Man-made ${ }^{129} \mathrm{I}$ originates primarily from fission of ${ }^{235} \mathrm{U}$ and ${ }^{239} \mathrm{Pu}$ with isobaric yields for fission induced by thermal neutrons of $0.68 \%$ and $1.6 \%$, respectively; iodine is produced in thermal fission of ${ }^{235} \mathrm{U}$ with isotopic ratios of ${ }^{131} \mathrm{I} /{ }^{129} \mathrm{I}=$ 3.82 and ${ }^{129} \mathrm{I} /{ }^{127} \mathrm{I}=6.06$ (England and Rider 1994).

Estimates of the ${ }^{129} \mathrm{I}$ releases from explosions of nuclear weapons are between $43 \mathrm{~kg}(0.28 \mathrm{TBq})$ and 150 kg (0.98 TBq) (Carter and Moghissi, 1977; UNSCEAR 1982; Chamberlain, 1991; Eisenbud and Gesell, 1997). Schmidt et al. (1998) estimated that the Chernobyl accident released less than $2 \mathrm{~kg}(0.013 \mathrm{TBq})$ of ${ }^{129} \mathrm{I}$. The vast amount of man-made ${ }^{129} \mathrm{I}$ in the environment is due to releases from reprocessing plants. For example, about $3500 \mathrm{~kg}(23 \mathrm{TBq})$ of ${ }^{129} \mathrm{I}$ were released from European reprocessing plants up to the year 2000 , of this $70 \%$ being by the La Hague reprocessing plant (Raisbeck et al., 1995; Gray et al., 1995; Parker, 2001; Webmaster Cogema, 2001; BNFL, 1999; Groupe radioécologique Nord-Cotentin, 1999). Of the ${ }^{129} \mathrm{I}$ emissions from La Hague $97 \%$ were liquid discharges, compared with $85 \%$ from Sellafield. Large amounts of man-made ${ }^{129}$ I are still stored in spent nuclear fuel, estimated to be $5660 \mathrm{~kg}$ (37 TBq) in 1990 (Finkel and Suter, 1993). There is little information about the releases from U.S. military reprocessing plants (Moran et al., 1999); nothing is published about plants in the former USSR and other eastern countries. 
Man-made ${ }^{129}$ I enters the environmental iodine cycles and changes the natural iodine isotopic abundances. The natural ${ }^{129} \mathrm{I} /{ }^{127} \mathrm{I}$ ratios in the oceanic mixing layer have been globally changed by two orders of magnitude from about $1.5 \cdot 10^{-12}$ (Schink et al., 1995; Moran et al., 1998) to about $10^{-10}$ in areas remote from emissions and with orders of magnitude higher ratios close to the release points (Yiou et al., 1994). Though these changes are of radiological relevance only in the closest proximity to reprocessing plants, they should be carefully monitored and the potential of ${ }^{129} \mathrm{I}$ as a man-made tracer for environmental processes should be exploited. This requires a detailed understanding of the pre-nuclear baseline values, of the anthropogenic changes, of the radioecology of ${ }^{129} \mathrm{I}$ and of the environmental chemistry of iodine. However, the radioecology of ${ }^{129} \mathrm{I}$ is still insufficiently known due to analytical and methodological problems (Schmidt et al., 1998). Systematic investigations to establish reliable analytical protocols for ${ }^{129} \mathrm{I}$ and ${ }^{127} \mathrm{I}$ analyses in various environmental materials have since been established to close some gaps in our knowledge about the radioecology of ${ }^{129} \mathrm{I}$ (Schmidt, 1998; Schmidt et al., 1998; Szidat et al., 2000c; Szidat, 2000; Szidat et al., 2000b; Ernst et al., 2002; Ernst et al., 2003).

The analysis of ${ }^{129} \mathrm{I}$ in environmental samples, in particular in soils, offers an opportunity for the retrospective dosimetry of the radiation exposure caused by short-lived iodine isotopes, such as ${ }^{131} \mathrm{I}$, long after the radionuclides were released in accidents or incidents. There are several requirements for this retrospective dosimetry to be feasible. The ${ }^{129} \mathrm{I}$ from the accident must not have disappeared from the analyzed soil horizons by migration into deeper soil layers and it must be distinguishable from potentially existing fallout prior to accident. Finally, the radioecological modeling connecting the deposition density of ${ }^{131}$ I derived from the observed ${ }^{129} \mathrm{I}$ deposition densities with the thyroid dose must be reliable. 
The mathematical model underlying the retrospective dosimetry of ${ }^{131} \mathrm{I}$ exposures using ${ }^{129} \mathrm{I}$ is given by equation 1 .

$$
H_{\text {thyr }}=\left(D\left({ }^{129} \mathrm{I}\right)-D_{\text {pre-Ch. }}\left({ }^{129} \mathrm{I}\right)\right) \cdot \frac{A_{131}}{A_{129}} \cdot D C_{131} \cdot f(t)
$$

where

$H_{\text {thyr }} \quad$ is the committed equivalent dose to the thyroid due to ${ }^{131} \mathrm{I}$ in $\mathrm{Sv}$,

$D\left({ }^{129} \mathrm{I}\right) \quad$ the integral ${ }^{129} \mathrm{I}$ deposition density at a location in $\mathrm{Bq} \mathrm{m}^{-2}$,

$\left.D_{\text {pre-Ch. }}{ }^{129} \mathrm{I}\right) \quad$ the integral ${ }^{129} \mathrm{I}$ deposition density from pre-Chernobyl fallout in $\mathrm{Bq} \mathrm{m}^{-2}$,

$\frac{A_{131}}{A_{129}} \quad$ the activity ratio of ${ }^{131} \mathrm{I}$ and ${ }^{129} \mathrm{I}$ at the time of the accident,

$D C_{131} \quad$ an aggregated dose coefficient for ${ }^{131} \mathrm{I}$ exposure of the thyroid for a single fallout event in $\mathrm{Sv} \mathrm{Bq}^{-1} \mathrm{~m}^{2}$ derived from a radioecological model,

a correction factor which accounts for the decay of ${ }^{131} \mathrm{I}$ between the accident and arrival of the ${ }^{131} \mathrm{I}$ at the location of the exposure.

In principle, ${ }^{129} \mathrm{I}$ in equation 1 could be substituted by other radionuclides, such as ${ }^{137} \mathrm{Cs}$ or ${ }^{90} \mathrm{Sr}$, if the emission and atmospheric transport are homogeneous as for the global weapons fallout. In the case of the Chernobyl accident, however, the different elements were chemically differentiated during the explosion and the subsequent emissions and were further differentiated by a time dependent atmospheric transport in the troposphere as plumes with differing elemental compositions; see UNSCEAR (2000) and references therein.

This work is part of an ongoing radioecological project by which the environmental behaviour of various radionuclides released by the Chernobyl accident and the resulting radiation exposure of the inhabitants in the highly contaminated areas in Northern Ukraine are studied (Schmidt, 1998; 
Schmidt et al., 1998; Filss et al., 1998; Slavov et al., 1999; Botsch, 2000; Botsch et al., 2000; Handl et al., 2003; Mewis, 2004). Here, we deal with the analysis of ${ }^{127} \mathrm{I}$ and ${ }^{129} \mathrm{I}$ in soils from Russia and Northern Ukraine and investigate the feasibility of using ${ }^{129} \mathrm{I}$ as an indicator for ${ }^{131} \mathrm{I}$ fallout after the Chernobyl accident. We discuss the various input quantities on which retrospective dose estimates depend and present the results of a retrospective dosimetry of the exposure to ${ }^{131} \mathrm{I}$ for people living in some villages in the Korosten and Narodici districts of Northern Ukraine. Some preliminary data for ${ }^{129}$ I from this work have been reported by Schmidt et al. (1998) and Michel et al. (2000, 2002a, $2002 b, 2002 c)$.

There are several earlier publications dealing with the retrospective dosimetry of ${ }^{131}$ I exposures using ${ }^{129}$ I (Straume et al., 1996; Robl et al., 1997; Mironov et al., 1999, 2002; Reithmeier et al., 2002; Pietrzak-Flis et al., 2003). Most of the earlier work aimed at evaluating the feasibility of ${ }^{129} \mathrm{I}$ retrospective dosimetry and on determining some of the input quantities of equation 1. Only Robl et al. (1997) and Pietrzak-Flis et al. (2003) did complete evaluations ending up with thyroid dose estimates.

\section{Experimental}

We investigated 2 soil profiles from Moscow/Russia and 42 soil profiles from Northern Ukraine taken in 1995 and 1997, respectively. The sampling sites covered areas almost not affected by fallout from the Chernobyl accident such as Moscow/Russia and Zhitomir/Ukraine as well as moderately and highly contaminated regions of Northern Ukraine in the Korosten and the Narodici districts, respectively (Fig. 1). According to an early categorization (Law of Ukraine, 1991) the sampling sites in Korosten belong to the contamination zone III with ${ }^{137} \mathrm{Cs}$ deposition densities between $185 \mathrm{kBq} \mathrm{m}^{-2}$ and $555 \mathrm{kBq} \mathrm{m}^{-2}\left(5-15 \mathrm{Ci} \mathrm{km}^{-2}\right)$, those in Narodici to the contamination zone II with 
${ }^{137} \mathrm{Cs}$ deposition densities between $555 \mathrm{kBq} \mathrm{m}$ and $1480 \mathrm{kBq} \mathrm{m}^{-2}\left(15-40 \mathrm{Ci} \mathrm{km}^{-2}\right)$. Zone $\mathrm{I}$ is the exclusion zone inside the $30 \mathrm{~km}$ cycle around the Chernobyl nuclear power plant (CNPP).

The Zhitomir district is located $160 \mathrm{~km}$ to the southwest from the CNPP; this district is considered to be the most weakly contaminated part of the Northern Ukraine. The sampling area included the following settlements: Baraschevka, Davidovka, Levkov, and Oserjanka. The Korosten district is situated $120 \mathrm{~km}$ west of CNPP which is expected to be a moderately contaminated area of zone III. The samples were collected in the vicinity of the villages Nemirovka, Woronewo, Tschigiri, and Kupetsch. The Narodici district is located at the distance of about $70 \mathrm{~km}$ from CNPP in the extreme west of zone II. It represents one of the most highly contaminated areas of Ukraine. The soil profiles were taken in environments surrounding three settlements: Christinovka, Novo Scharno, and Nosdrischtsche.

All sampling sites were chosen at state and private farms at locations without bushes and trees with reportedly constant land use and not affected by human activities during recent decades and which should represent undisturbed soils. At each plot, up to 7 soil profiles randomly distributed within an area of about $4 \mathrm{~km}^{2}$ were sampled.

To take the soil profiles $20 \times 20$-cm soil blocks were collected. To this end, $45 \mathrm{~cm}$-deep holes with surface areas of $1 \times 1 \mathrm{~m}$ were dug leaving $20 \times 20-\mathrm{cm}$ soil columns in a corner. These columns were sectioned at $1-\mathrm{cm}$ intervals within a top $5-\mathrm{cm}$ layer, then $5-\mathrm{cm}$ intervals down to $25 \mathrm{~cm}$ and a final interval to a depth of $40 \mathrm{~cm}$. After determining the fresh weight, the material was dried at room temperature, milled, and thereafter sieved through a 2-mm mesh sieve; see Handl et al. (2003) for details of sampling. 
The samples were analysed for ${ }^{129} \mathrm{I}$ by radiochemical neutron activation analysis (RNAA) and accelerator mass spectrometry (AMS), for ${ }^{127}$ I by RNAA and ion chromatography (IC), and for ${ }^{137} \mathrm{Cs}$ and ${ }^{134} \mathrm{Cs}$ by $\gamma$-spectrometry.

RNAA turned out to be only capable of determining ${ }^{129}$ I in top-soils; see Schmidt et al. (1998) for details. For deeper layers, ${ }^{129}$ I could only be determined via AMS. With maximum sample masses of $80 \mathrm{~g}$ a detection limit according to ISO $11929-7$ (ISO, 2003) of $1 \mu \mathrm{Bq} \mathrm{kg}^{-1}$ and $1.8 \mathrm{mBq} \mathrm{kg}^{-1}$ for ${ }^{129}$ I was achieved by AMS and RNAA, respectively. Typical detection limits of ${ }^{127}$ I were $90 \mathrm{ng} \mathrm{g}^{-1}$ and $60 \mathrm{ng} \mathrm{g}^{-1}$ for RNAA and IC, respectively (Schmidt et al., 1998). By combining results from AMS and IC analyses ${ }^{129} \mathrm{I} /{ }^{127} \mathrm{I}$-ratios in soils were detectable down to $5 \cdot 10^{-12}$.

The ${ }^{129} \mathrm{I}$ blank values of the total analyses were determined with Woodward iodine as trace catcher. Typical blank ${ }^{129} \mathrm{I} /{ }^{127} \mathrm{I}$ ratios of the total analyses performed in two different laboratories were in terms of geometric means and standard deviations ${ }^{1}\left(1.3 \times 2.0^{ \pm 1}\right) \cdot 10^{-12}$ and $\left(3.5 \times 1.7^{ \pm 1}\right) \cdot 10^{-13}$, respectively (Ernst et al., 2003).

The experimental relative standard uncertainties of the concentrations of the iodine isotopes were between $2.8 \%$ and $21 \%$ for ${ }^{127} \mathrm{I}$ and between $4.4 \%$ and $56 \%$ (RNAA), respectively $19 \%$ (AMS) for ${ }^{129} \mathrm{I}$. The average relative uncertainties were $9.0 \%$ in the case of ${ }^{127} \mathrm{I}$ and $9.3 \%$ in the case of ${ }^{129} \mathrm{I}$.

1 In this paper, we use the convenient notation of e.g. $1.3 \times 2.0^{ \pm 1}$ to present geometric means and geometric standard deviations in analogy to the frequently used notation of e.g. $1.5 \pm 0.3$ when reporting arithmetic means and standard deviations. For an assumed logarithmic normal distribution, one obtains an interval containing about $66 \%$ of the data by multiplying, respectively by dividing, the geometric mean by the geometric standard deviation. 
Detailed descriptions of the sample preparations, the analytical techniques (AMS, RNAA, and IC), and quality control measures and on participation in round robin exercises (Roberts et al., 1997; Roberts and Caffee, 2000) are given elsewhere (Schmidt et al., 1998; Szidat et al., 2000a, 2000b, 2000c; Ernst et al., 2003).

As it was not feasible to analyze all depth profiles in detail for ${ }^{127} \mathrm{I}$ and ${ }^{129} \mathrm{I}$, the deposition densities of 30 depth profiles were determined by analysis of bulked or mixed samples. These were prepared from the individual profile samples so that they allowed calculation of the total activities in each profile. Since for ${ }^{137} \mathrm{Cs}$ all samples from each depth profile had been measured by gammaspectrometry (Botsch, 2000; Botsch et al., 2000; Handl et al., 2003) the quality of this procedure could be checked. The ratio of the ${ }^{137} \mathrm{Cs}$ deposition densities determined from individual soil profile samples to those determined from mixed samples was $0.99 \pm 0.07$, thus demonstrating the feasibility of the procedure.

\section{Experimental results}

The numerical results of all the analyses reported in this work can be obtained from the internet at www.zsr.uni-hannover.de. Detailed results for ${ }^{137} \mathrm{Cs}$ and ${ }^{134} \mathrm{Cs}$ in the soil profiles dealt with in this paper and for the radiation exposure due to ${ }^{137} \mathrm{Cs}$ were recently published (Handl et al., 2003).

Prior to this study, a screening investigation had been performed on ${ }^{129} \mathrm{I}$ and ${ }^{127} \mathrm{I}$ in 51 samples of top soils $(\mathrm{d} \leq 10 \mathrm{~cm})$ from various affected and unaffected locations in Ukraine, Belarus and Russia sampled between September 1991 and October 1992 using RNAA (table 1). The distances between the sampling locations of these top soils and the Chernobyl reactor ranged from $0.8 \mathrm{~km}$ to more than $400 \mathrm{~km}$. The variability of the ${ }^{129} \mathrm{I}$ specific activities was much larger than that of the ${ }^{127} \mathrm{I}$ concentrations and the maximum of the ${ }^{129} \mathrm{I}$ specific activities exceeded that of measurements of soils from 
Northern Germany by an order of magnitude. The results showed clearly that the ${ }^{129}$ I fallout from the Chernobyl accident could be identified in the soils. It was also seen that the variability of the ${ }^{129} \mathrm{I} /{ }^{127} \mathrm{I}$ isotopic ratios in the top soils was much larger than that of the ${ }^{129} \mathrm{I}$ specific activities. The latter observation could only be explained by differences in the ${ }^{127} \mathrm{I}$ concentrations of the soils which must not be neglected when interpreting ${ }^{129} \mathrm{I}^{127} \mathrm{I}$ isotopic ratios. Therefore, the ${ }^{127} \mathrm{I}$ concentrations shall be presented first.

\subsection{Depth profiles of ${ }^{127}$ I}

For all those samples measured by RNAA ${ }^{127}$ I data are available, i.e. data exist typically for the upper $10 \mathrm{~cm}$. For those samples investigated by AMS, complete analyses of ${ }^{127} \mathrm{I}$ by IC were only performed for a subset of four depth profiles. The mixed samples were analyzed for ${ }^{129}$ I only.

The ${ }^{127} \mathrm{I}$ concentrations range from $0.42 \mathrm{mg} \mathrm{kg}^{-1}$ to $8.0 \mathrm{mg} \mathrm{kg}^{-1}$, well in agreement with the range observed in the earlier screening measurements of topsoil samples. In Fig. 2, the four complete ${ }^{127} \mathrm{I}$ concentration depth profiles are shown. The concentrations are fairly uniform with depth for the individual profiles, but show remarkable differences between the four locations. The data vary by about a factor of ten. The variability of the experimental data is not due the experimental standard uncertainties, which ranged from $3 \%$ to $21 \%$ with an average of $9 \%$.

In the following, we frequently make use of the inventory of ${ }^{127} \mathrm{I}$ and ${ }^{129} \mathrm{I}$ within individual depth increments, in units of $\mathrm{g} \mathrm{m}^{-2}$ and $\mathrm{mBq} \mathrm{m}^{-2}$, respectively, calculated according to equation 2 :

$$
A_{\mathrm{F}}\left(d_{\max }, d_{\min }\right)=\int_{d_{\max }}^{d_{\min }} C(d) \cdot \rho(d) \mathrm{d} d
$$


with $d_{\max }=40 \mathrm{~cm}$ being the maximum sampling depth, $d_{\min }$ the depth of the top of the actual sampling interval, $C(d)$ the specific activity or mass concentration at depth $d$ of ${ }^{129} \mathrm{I}$ and ${ }^{127} \mathrm{I}$, respectively, and $\rho(d)$ the bulk density of the air-dried soil at depth $d$.

Provided that all fallout nuclides are contained in the sampled depth $d_{\max }=40 \mathrm{~cm}$ the total inventory $D$ is given by

$$
D \approx A_{\mathrm{F}}\left(d_{\max }, 0\right)=\int_{d_{\max }}^{0} C(d) \cdot \rho(d) \mathrm{d} d .
$$

The depth dependence of the inventories within individual depth increments of ${ }^{127} \mathrm{I}$ is shown in Fig. 2 for the four soil profiles from Moscow, Nemirovka, and Nosdrischtsche. Interpreting the $A_{\mathrm{F}, 127}\left(d_{\mathrm{max}}, 0\right)$ as the time integrated total inventory $D_{127}$ of ${ }^{127} \mathrm{I}$, the data from Fig. 2 would imply that there were differences in the ${ }^{127} \mathrm{I}$ atmospheric input of nearly a factor of ten. This appears rather unlikely. Different iodine concentrations in air and precipitation are only to be expected on large scales over landmasses. Thus, the observed differences can only be attributed to the different soil characteristics and hydrological conditions. Low ${ }^{127} \mathrm{I}$ concentrations and consequently low total inventories point to a significant loss of stable iodine over the long times of atmospheric input. High ${ }^{127}$ I concentrations and high total inventories point to lower, but still unaccountable loss of iodine and therefore should be a better proxy of the real integral deposition density of stable iodine. High total inventories point to a smaller migration into depth and to a more efficient sorption or accumulation in the particular soil, low ones to a higher migration and less efficient sorption or accumulation. We shall come back to this when discussing the ${ }^{129} \mathrm{I}$ depth profiles.

As a consequence of the different transport processes involved in the migration of iodine in the soils, the long-term fallout of ${ }^{127} \mathrm{I}$ is expected to result in an exponential decrease of inventories within individual depth increments over the depth of the soil. The ${ }^{127}$ I inventories within individual depth increments are coarsely in agreement with this expectation (Fig. 2). They decrease exponen- 
tially with characteristic lengths between $19 \mathrm{~cm}$ and $24 \mathrm{~cm}$. The total inventories of ${ }^{127}$ I range from $0.39 \mathrm{~g} \mathrm{~m}^{-2}$ to $3.4 \mathrm{~g} \mathrm{~m}^{-2}$ with a geometric mean of $0.9 \mathrm{~g} \mathrm{~m}^{-2}$ and a geometric standard deviation of 2.6. The inventories within individual depth increments decrease by factors of about three over the entire depth profiles.

The differences between the total inventories at the different locations indicate that substantial amounts of stable iodine which was input over thousands of years have been lost at the various locations into the deeper, water-saturated soil zones due to individual soil characteristics, hydrological conditions, and hydrodynamic dispersion. With this conclusion it becomes a crucial question whether the water-unsaturated soil zones are sufficient archives to preserve ${ }^{129}$ I for the purpose of a retrospective dosimetry of ${ }^{131} \mathrm{I}$. This will be discussed below.

\subsection{Depth profiles of ${ }^{129} \mathrm{I}$}

The ${ }^{129}$ I specific activities measured in the depth profiles span nearly four orders of magnitude, ranging from $0.006 \mathrm{mBq} \mathrm{kg}^{-1}$ to $24.5 \mathrm{mBq} \mathrm{kg}^{-1}$. Only in two samples of the initial screening investigation of top soils were higher ${ }^{129}$ I specific activities observed: $52 \mathrm{mBq} \mathrm{kg}^{-1}$ in a sample from the proximity of Gomel in Belarus and $111 \mathrm{mBq} \mathrm{kg}^{-1}$ in a top soil sampled $0.8 \mathrm{~km}$ from the Chernobyl reactor.

Examples of the depth dependencies of ${ }^{129}$ I specific activities in the differently contaminated areas are shown in Fig. 3. For the areas not significantly affected by Chernobyl fallout they decrease from $\sim 1 \mathrm{mBq} \mathrm{kg}{ }^{-1}$ at the surface to $\sim 0.01 \mathrm{mBq} \mathrm{kg}^{-1}$ in the lowest layer. ${ }^{129}$ I specific activities decrease nearly monotonically in the two profiles from Moscow and in Levkov 2, while in the profile Levkov 1 a local maximum appears in the layer from 5 to $10 \mathrm{~cm}$. In the profiles from zone III, ${ }^{129} \mathrm{I}$ specific activities decrease also nearly monotonically: the profile from Woronewo 4 from 10 
$\mathrm{mBq} \mathrm{kg}{ }^{-1}$ to $0.1 \mathrm{mBq} \mathrm{kg}{ }^{-1}$, those from Nemirovka and Kupetsch-Tschernjanka from values larger than $1 \mathrm{mBq} \mathrm{kg}^{-1}$ to $0.01 \mathrm{mBq} \mathrm{kg}^{-1}$.

The profiles from Nosdrischtsche and Christinovka in zone II look different than the other ones. The profile from Christinovka river shore shows a local maximum of $24.5 \mathrm{mBq} \mathrm{kg}^{-1}$ in the 2 to 3 $\mathrm{cm}$ layer, followed by a monotonous decrease down to $0.1 \mathrm{mBq} \mathrm{kg}{ }^{-1}$. The Christinovka meadow profile generally shows relatively low $\left(1.1 \mathrm{mBq} \mathrm{kg}^{-1}\right.$ to $\left.0.2 \mathrm{mBq} \mathrm{kg}{ }^{-1}\right)$ specific activities. After a short decrease from surface, they exhibit a broad maximum extending from $10 \mathrm{~cm}$ to $30 \mathrm{~cm}$ depth. All the specific activities change by just one order of magnitude over the entire profile while for all the other profiles of all locations the specific activities drop by two orders of magnitude.

\section{$3.3^{129} \mathrm{I} /{ }^{127} \mathrm{I}$ isotopic ratios}

The ${ }^{129} \mathrm{I} /{ }^{127} \mathrm{I}$ isotopic ratios in the four completely analyzed soil profiles are presented in Fig. 4. For Moscow and Nemirovka 2, they decrease monotonically from the surface into the depth. The surface ratios are between $2 \times 10^{-8}$ and $5 \times 10^{-8}$. At depth, they differ by about an order of magnitude between $3 \times 10^{-10}$ and $3.5 \times 10^{-9}$. For the profile Nosdrischtsche 2, the ${ }^{129} \mathrm{I} /{ }^{127} \mathrm{I}$ isotopic ratios increase from $3 \times 10^{-7}$ at the surface to more than $10^{-6}$ between 10 and $20 \mathrm{~cm}$. Below $20 \mathrm{~cm}$ they decrease by more than an order of magnitude to $2 \times 10^{-8}$. For all the profiles, even the deepest samples are affected by man-made ${ }^{129} \mathrm{I}$. The lowest isotopic ratios at depth exceeded the pre-nuclear marine equilibrium ratios by more than 2 orders of magnitude and the lowest ratio measured so far, a prenuclear soil at $(5.7 \pm 1.1) \times 10^{-12}$ (Szidat et al., 2000b) by a factor of 50 . The range of ${ }^{129} \mathrm{I}^{127} \mathrm{I}$ isotopic ratios observed in the screening measurements (table 1) is slightly larger than that measured in the four profiles reflecting the wider sampling area. 


\subsection{Integral deposition densities of ${ }^{129} I$ in Ukraine}

Inventories within individual depth increments of ${ }^{129} \mathrm{I}$ and ${ }^{137} \mathrm{Cs}$ were calculated from the ${ }^{129} \mathrm{I}$ and ${ }^{137} \mathrm{Cs}$ specific activities in the depth profiles according to equation 2 as proxy for the integral deposition densities (table 2). The profiles of these inventories are presented in Fig. 5.

In contrast to the respective data for ${ }^{127} \mathrm{I}$ (Fig. 2), the inventories within individual depth increments of ${ }^{129} \mathrm{I}$ and ${ }^{137} \mathrm{Cs}$ decrease with depth by about two orders of magnitude, much steeper than those of ${ }^{127}$ I. Even the profiles from the areas not affected by the Chernobyl accident, i.e. Moscow, Levkov and Baraschevka, show this behaviour. This supports the assumption that most of the fallout is still confined to the topmost $40 \mathrm{~cm}$. In the lowest layers $(25$ to $40 \mathrm{~cm})$ of the depth profiles, we observe only between $1 \%$ and $10 \%$ of the total ${ }^{129} \mathrm{I}$ and even less in case of ${ }^{137} \mathrm{Cs}$ (down to $0.2 \%$ ).

In table 3 the results of the total inventories of ${ }^{129} \mathrm{I}$ are summarized and compared with data for a pre-nuclear soil from Lutinovo in Russia (Szidat et al., 2000b) and from a recent investigation of 7 deep depth profiles from Lower Saxony, Germany (Ernst et al., 2003).

All the total inventories are at least three orders of magnitude higher than a value of $0.084 \pm 0.017$ $\mathrm{mBq} \mathrm{\textrm {m } ^ { - 2 }}$ derived from a pre-nuclear soil profile taken in 1939 in Lutovinovo/ Russia (Szidat et al., $2000 \mathrm{~b})$. The geometric means and standard deviations of the total ${ }^{129} \mathrm{I}$ inventories are $49 \times 1.5^{ \pm 1}$ $\mathrm{mBq} \mathrm{m}{ }^{-2}$ for samples from Moscow, $38 \times 1.7^{ \pm 1} \mathrm{mBq} \mathrm{m}^{-2}$ for samples from Zhitomir/Ukraine, $130 \times$ $1.5^{ \pm 1} \mathrm{mBq} \mathrm{m}^{-2}$ for samples from contamination zone III and $848 \times 1.5^{ \pm 1} \mathrm{mBq} \mathrm{m}^{-2}$ for those from contamination zone II.

The logarithmic means of the total ${ }^{137} \mathrm{Cs}$ inventories of $4.1 \times 1.2^{ \pm 1} \mathrm{kBq} \mathrm{m}{ }^{-2}$ for Moscow, $4.6 \times 1.2^{ \pm 1}$ $\mathrm{kBq} \mathrm{m}{ }^{-2}$ for Zhitomir, and $4.8 \times 1.4^{ \pm 1} \mathrm{kBq} \mathrm{m}^{-2}$ for Lower Saxony are well in agreement and confirm 
the negligible influence of Chernobyl fallout at these locations. They are dominated by global fallout of ${ }^{137} \mathrm{Cs}$ from atmospheric nuclear explosions.

For ${ }^{129} \mathrm{I}$, the results for the soil profiles from Moscow and Zhitomir are significantly lower than those obtained from seven soil profiles taken in 1999 near Hanover in Lower Saxony/Germany which showed total inventories of $168 \times 1.1^{ \pm 1} \mathrm{mBq} \mathrm{m}^{-2}$ (Ernst et al., 2003). Thus, it appears that Western Europe is more affected by recent fallout of ${ }^{129} \mathrm{I}$ as a consequence of emissions from the European reprocessing plants in La Hague and Sellafield than Ukraine and Russia. While for Western Europe the ongoing fallout of ${ }^{129} \mathrm{I}$ has been investigated (Szidat et al., 2000b; Schnabel et al., 2001), for Ukraine or Russia no such investigations exist up to now.

The ratios $D\left({ }^{129} \mathrm{I}\right) / D\left({ }^{137} \mathrm{Cs}\right)$ of the total inventories of ${ }^{129} \mathrm{I}$ and of ${ }^{137} \mathrm{Cs}$ give some evidence for the origin of environmental ${ }^{129} \mathrm{I}$, since ${ }^{129} \mathrm{I}$ and ${ }^{137} \mathrm{Cs}$ from nuclear explosions should represent the isobaric fission yields while from reprocessing plants ${ }^{129} \mathrm{I}$ is preferentially emitted. In Moscow and around Zhitomir, the ratios $D\left({ }^{129} \mathrm{I}\right) / D\left({ }^{137} \mathrm{Cs}\right)$ show a geometric mean of $8.5 \times 10^{-6}$ with a geometric standard deviation of 1.6. In zones III and II, the ratios $D\left({ }^{129} \mathrm{I}\right) / D\left({ }^{137} \mathrm{Cs}\right)$ are nearly two orders of magnitude lower. In zone III, they show a geometric mean of $2.0 \times 10^{-7}$ with a geometric standard deviation of 1.9 , and in zone II a geometric mean of $2.8 \times 10^{-7}$ with a geometric standard deviation of 1.3. The latter two mean ratios are close to what one expects according to equation 4 for the activity ratio $A_{\text {fission }}\left({ }^{129} \mathrm{I}\right) / A_{\text {fission }}\left({ }^{137} \mathrm{Cs}\right)$ in fallout from atmospheric weapon tests and in undifferentiated Chernobyl debris.

$$
\frac{A_{\text {fission }}\left({ }^{129} \mathrm{I}\right)}{A_{\text {fission }}\left({ }^{137} \mathrm{Cs}\right)}=\frac{Y(129) \cdot \lambda\left({ }^{129} \mathrm{I}\right)}{Y(137) \cdot \lambda\left({ }^{137} \mathrm{Cs}\right)}=\frac{0.0065 \cdot 1,4 \cdot 10^{-15} \mathrm{~s}^{-1}}{0.0626 \cdot 7.3 \cdot 10^{-10} \mathrm{~s}^{-1}}=2.0 \times 10^{-7}
$$

with 
$Y(A)$ being the fission yield of the isobars $A=129$ and $A=137$ and

$\lambda \quad$ the decay constants of ${ }^{129} \mathrm{I}$ and ${ }^{137} \mathrm{Cs}$.

In zone II, the ratios $D\left({ }^{129} \mathrm{I}\right) / D\left({ }^{137} \mathrm{Cs}\right)$ are just slightly higher than the fission value and show a small variability. In zone III, they match the fission value on the average, but the individual ratios are spread over an order of magnitude. The nearly two orders of magnitude higher ratios in Moscow and around Zhitomir clearly indicate the existence of another additional source of ${ }^{129}$ I, most likely the effect of the European reprocessing plants. The total inventories of ${ }^{129}$ I support this interpretation since they are much higher than the total ${ }^{129}$ I inventories due to fallout of atmospheric nuclear explosions in the northern hemisphere. Estimate of the weapons fallout of ${ }^{129} \mathrm{I}$ are between $1.4 \mathrm{mBq}$ $\mathrm{m}^{-2}$ (Rao and Fehn, 1999) and $2.9 \mathrm{mBq} \mathrm{m}^{-2}$ (Oktay et al., 2000; Schink et al., 1995).

\section{Discussion}

The discussion will first focus on the migration behavior of the iodine isotopes in soils. Then, we shall discuss the individual input data for a retrospective dosimetry of ${ }^{131} \mathrm{I}$ exposures according to equation 1.

\subsection{Migration of Iodine and deposition densities of ${ }^{127} I$ and ${ }^{129} I$}

As in most migration studies, the soil profiles investigated in this work sample only the upper water-unsaturated soil zone. There, the ${ }^{127}$ I concentrations are fairly constant in the individual depth profiles but vary considerably from one location to another. This is in accordance with the results of an investigation of seven deeper soil profiles from Lower Saxony, Germany with depths down to $2.5 \mathrm{~m}$ (Ernst et al., 2003). It was also observed that the ${ }^{129} \mathrm{I}$ concentrations were fairly uniform with depth for the individual profiles in the upper, unsaturated soil zones; they steeply decreased at deeper layers from about $1 \mathrm{mg} \mathrm{kg}^{-1}$ down to $0.06 \mathrm{mg} \mathrm{kg}^{-1}$. This observation was independent of land 
use and, since these depth profiles were completely analyzed with respect to their soil characteristics, cannot be explained by different biological activities or bioturbation.

The differences observed in the ${ }^{127}$ I concentrations and total inventories can only be explained by differences in the migration behavior in the soil. As discussed by Ernst et al. (2003) in detail, the natural stable iodine concentrations in the soils cannot be explained by the iodine concentrations in the bedrock, but are the result of wet and dry deposition of atmospheric iodine originating from the sea. They are the result of an input over thousands of years since the annual deposition density rates from precipitation are only in the range from $1 \mathrm{mg} \mathrm{m}^{-2} \mathrm{a}^{-1}$ to $6 \mathrm{mg} \mathrm{m}^{-2} \mathrm{a}^{-1}$ (Szidat et al., 2000b). Over long time spans, the differences in the apparent integral deposition densities of ${ }^{127} \mathrm{I}$ cannot be explained by variations due to wet and dry deposition as long as one does not compare forested and non-forested landscapes.

The iodine concentrations in the water-unsaturated soil zone are the result of the competition between downward migration and accumulation via upward directed evapo-transpiration. Migration is the movement of iodine from the surface into the deeper layers of the soil as a consequence of various transporting processes. The processes resulting in the migration may also contribute to an accumulation of the iodine in certain upper layers of the soil. Accumulation of a substance, contained in precipitation and consequently transported into the soil water as dissolved material, as particulate matter or as colloids, is an increase of its concentration in the water-unsaturated zone (upper soil) by evaporation of water. The evaporation process forces the water to move into the opposite direction of the migration, without the latter being excluded. Diffusion boundary layers, which are formed from adsorbed water and capillary water at the soil matrix, contribute to the accumulation and different modes of physical and chemical sorption which occur on widely differing time scales influence the accumulation and migration. Iodine which reaches the water-saturated soil zones disappears from the system via ground leachate and water transport and, consequently, the differing 
${ }^{127}$ I integral deposition densities can well be explained by loss of the stable iodine from the soil over long time spans.

The question whether ${ }^{129} \mathrm{I}$ from recent fallout was lost by migration from the sampled depth interval is essential for the retrospective dosimetry. From the existing data of ${ }^{129} \mathrm{I}$ we cannot obtain evidence of what losses might occur on short time scales of tens of years. However, the data of Fig. 5 indicate that the pre- and post-Chernobyl man-made ${ }^{129} \mathrm{I}$ is still confined to the topmost $40 \mathrm{~cm}$, but we cannot quantify how much of the ${ }^{129} \mathrm{I}$ has been lost. The investigation of the soil profiles from Lower Saxony, Germany demonstrated that man-made ${ }^{129} \mathrm{I}$ has reached a depth of $2.5 \mathrm{~m}$ (Ernst et al., 2003). The lowest observed ${ }^{129} \mathrm{I}^{127} \mathrm{I}$ isotopic ratios were $\sim 10^{-10}$. However, between $77 \%$ and $96 \%$ of the ${ }^{129} \mathrm{I}$ in the soil profiles from Lower Saxony was found in the topmost $40 \mathrm{~cm}$. For ${ }^{127} \mathrm{I}$, only between $17 \%$ and $81 \%$ were in the upper $40 \mathrm{~cm}$.

A comparison of the depth dependencies of the inventories within individual depth increments of ${ }^{129} \mathrm{I}$ and ${ }^{137} \mathrm{Cs}$ demonstrates significant differences between the migration behaviours of the two radionuclides. This is shown for the profiles from areas not affected by the Chernobyl fallout in Fig. 5. The depth dependencies of ${ }^{137} \mathrm{Cs}$ generally are steeper than those of ${ }^{129} \mathrm{I}$ pointing to a higher mobility of the latter nuclide. The two profiles from Levkov are quite similar in the case of ${ }^{137} \mathrm{Cs}$, but differ considerably for ${ }^{129} \mathrm{I}$. Also for the upper part of the soil profile from Baraschevka different functional behaviors are seen. For the profiles from Moscow and for Baraschevka 1 no ${ }^{137} \mathrm{Cs}$ could be detected in the $25 \mathrm{~cm}$ to $40 \mathrm{~cm}$ layer.

Also the ${ }^{129}$ I depth profiles differ considerably for soils from zones III and II (Fig. 5). For the lowest soil layer sampled, the ${ }^{129}$ I inventories within individual depth increments show a much larger spread for samples from zone III than the total inventories, thus emphasizing the variability in migration at the different locations. Extremes are the depth profiles from Christinovka meadow and 
river shore. However, they also show that the migration of ${ }^{137} \mathrm{Cs}$ and ${ }^{129} \mathrm{I}$ run roughly parallel (Fig. 5). However, the ${ }^{129}$ I profiles have smaller gradients with depth than those of ${ }^{137} \mathrm{Cs}$. At the same time, Fig. 5 shows that the completely different migration situation at Christinovka meadow also affects ${ }^{137} \mathrm{Cs}$ in the same way, i.e. that the migration is faster in this location. The soil profile for Christinovka meadow is exceptional. Deviations of the ${ }^{137} \mathrm{Cs} /{ }^{134} \mathrm{Cs}$ activity ratio from the ratio of $1.88 \pm 0.05$ at the time of the Chernobyl accident (Handl et al., 2003) give evidence that even caesium from the Chernobyl accident has already reached the $25 \mathrm{~cm}$ to $40 \mathrm{~cm}$ depth region in the profile Christinovka meadow and that the ${ }^{137} \mathrm{Cs}$ from nuclear weapons fallout has already disappeared from the sampled soil column. Also a loss of ${ }^{129}$ I appears likely for this soil profile.

The ${ }^{129} \mathrm{I}^{127} \mathrm{I}$ depth dependencies of the different profiles (Fig. 4) are more difficult to interpret because they reflect a mixture of long-term effects for ${ }^{127} \mathrm{I}$ and of short-term ones for ${ }^{129} \mathrm{I}$. However, they can be understood by comparing them with the ${ }^{127}$ I inventories within individual depth increments (compare to Fig. 2). The observations in this work are consistent with those made by Ernst et al. (2003). A slower decrease with depth of the ${ }^{129} \mathrm{I} /{ }^{127} \mathrm{I}$ isotopic ratios is observed at locations with lower total ${ }^{127}$ I inventories and faster iodine migration. We observe the steepest ${ }^{129} \mathrm{I} /{ }^{127} \mathrm{I}$ decrease by two orders of magnitude in the profile from Nemirovka II which had the highest total ${ }^{127}$ I inventory, i.e. in the soil which accumulated the iodine best over even long time scales. For soil Moscow VII, which had a comparably low total ${ }^{127} \mathrm{I}$ inventory, the ${ }^{129} \mathrm{I} /{ }^{127} \mathrm{I}$ isotopic ratios decrease just by one order of magnitude. The soil Nosdrischtsche 2 had the smallest total ${ }^{127}$ I inventory pointing to a high migration and a low accumulation of iodine. Well in line with this, its ${ }^{129} \mathrm{I}{ }^{127} \mathrm{I}$ ratios exhibit their maximum at depth, the Chernobyl ${ }^{129}$ I already being substantially dislocated to depth.

In summary, one may conclude that a sampling depth of $40 \mathrm{~cm}$ appears to be sufficient to cover most of the recent fallout of ${ }^{129} \mathrm{I}$ and that the inventories in the sampled soil columns reveal the ${ }^{129} \mathrm{I}$ deposition densities. But, in view of the results from Lower Saxony, Germany (Ernst et al., 2003), 
there remains a caveat. These data can only be regarded as lower limits of the total inventories. In spite of that, we shall use them as a proxy for the total inventories.

\subsection{Pre-Chernobyl inventory of ${ }^{129} I$}

The feasibility of a retrospective ${ }^{131} \mathrm{I}$ dosimetry via ${ }^{129} \mathrm{I}$ also depends crucially on the question of whether the ${ }^{129}$ I from the Chernobyl fallout can be detected against the background of the preChernobyl ${ }^{129}$ I deposition as the result of the global weapon testing fallout and of liquid and aerial ${ }^{129} \mathrm{I}$ discharges from reprocessing plants and subsequent atmospheric transport. It was realized that this is a real problem when comparing the ${ }^{129}$ I specific activities with results for soils from Lower Saxony, Germany, where 25 samples of topsoil showed logarithmic means of ${ }^{129}$ I specific activities and of ${ }^{129} \mathrm{I}^{127} \mathrm{I}$ isotopic ratios of $1.7 \mathrm{mBq} \mathrm{kg}^{-1}$ and $5.9 \cdot 10^{-8}$ with geometric standard deviations of 1.7 and 3.6 , respectively.

In this work, we can estimate the pre-Chernobyl total inventory from the two soil profiles from Moscow, Russia and from 12 soil profiles from the vicinity of Zhitomir, Ukraine. Based on the total ${ }^{137} \mathrm{Cs}$ inventories and missing ${ }^{134} \mathrm{Cs}$ in these profiles, both regions are practically unaffected by the Chernobyl fallout and thus can serve for such an estimate. From the Moscow soils we estimate $D_{\text {pre-Ch. }}\left({ }^{129} \mathrm{I}\right)=(51 \pm 19) \mathrm{mBq} \mathrm{m}^{-2}$ (geometric mean and standard deviation $49 \mathrm{mBq} \mathrm{m}^{-2} \times 1.5^{ \pm 1}$ ), while the soils from Zhitomir give $D_{129, \text { pre-Ch. }}=(47 \pm 27) \mathrm{mBq} \mathrm{m}^{-2}$ (geometric mean and standard deviation: $38 \mathrm{mBq} \mathrm{m}^{-2}$ and 1.7). Combining our data from Moscow and from Zhitomir district we take $D_{\text {pre-Ch. }}\left({ }^{129} \mathrm{I}\right)=(44 \pm 24) \mathrm{mBq} \mathrm{m}^{-2}$ as our best estimate for the pre-Chernobyl total inventory of ${ }^{129} \mathrm{I}$.

This value of $44 \mathrm{mBq} \mathrm{m}^{-2}$ is much higher than that estimated for the global weapons fallout inventory of ${ }^{129} \mathrm{I}$ for which the estimates lie between $1.4 \mathrm{mBq} \mathrm{m}^{-2}$ and $2.9 \mathrm{mBq} \mathrm{m}^{-2}$ (Schink et al., 1995; 
Rao and Fehn, 1999; Oktay et al., 2000). Thus, it turns out that also in Eastern Europe a substantial amount of ${ }^{129} \mathrm{I}$ from emissions from reprocessing plants has been deposited.

For Eastern Europe just a few estimates of the pre-Chernobyl inventories exist (Straume et al., 1996; Reithmeier et al., 2002; Mironov et al., 1999, 2002). Robl et al. (1997) and Pietrzak-Flis et al. (2003) assumed the same pre-Chernobyl contribution to ${ }^{129} \mathrm{I}$ as Straume et al. (1996).

Straume et al. (1996) investigated the feasibility of ${ }^{131}$ I retrospective dosimetry via ${ }^{129}$ I. They analyzed soil samples from Belarus to a depth of $30 \mathrm{~cm}$ using AMS. They estimated the pre-Chernobyl ${ }^{129} \mathrm{I}$ in soils by analyzing a sample from San Joaquin valley in California, USA which showed a ${ }^{129} \mathrm{I}$ atom concentration of $6 \times 10^{7} \mathrm{~g}^{-1}$. Assuming this value as typical for a depth of $30 \mathrm{~cm}$ and a soil with a density of $1.5 \mathrm{~g} \mathrm{~cm}^{-3}$ this atom concentration is equivalent to a total inventory of $26 \mathrm{mBq} \mathrm{m}^{-2}$. The relative good agreement with our estimate appears to us accidental, since neither the latitude dependence of the atmospheric weapons fallout was considered nor the even more important influences of emissions from reprocessing plants which are different in Europe and in North America.

Reithmeier et al. (2002) reported some data on ${ }^{129} \mathrm{I}$ concentrations and ${ }^{129} \mathrm{~V}^{127} \mathrm{I}$ isotopic ratios for six lakes (Ammersee, Lago Maggiore, Lago di Garda, Baikal, Balkhash, and Issyk-kul) and discussed ${ }^{131}$ I dose reconstruction via ${ }^{129} \mathrm{I}$ in the former Soviet Union. They claimed that their data allowed estimation of pre-Chernobyl inventory of ${ }^{129} \mathrm{I}$ of $(7.4 \pm 1.3) \times 10^{12}$ atoms $\mathrm{m}^{-2} \cong(10.4 \pm 1.6) \mathrm{mBq} \mathrm{m}^{-2}$ (Lake Baikal) and $(8.5 \pm 3.1) \times 10^{12}$ atoms $\mathrm{m}^{-2} \cong(11.9 \pm 4.3) \mathrm{mBq} \mathrm{m}^{-2}$ (Lake Issyk-kul). Their estimates are significantly lower than our data for the pre-Chernobyl inventories in Russia and the Northern Ukraine.

Mironov et al. $(1999,2002)$ used ${ }^{129} \mathrm{I}$ and ${ }^{137} \mathrm{Cs}$ to estimate the total ${ }^{131}$ I inventories due to Chernobyl in Belarus. From the analysis of a pre-Chernobyl soil sample taken $400 \mathrm{~km}$ north of Chernobyl 
in 1985 and assuming a maximum penetration depth of $20 \mathrm{~cm}$, both for ${ }^{129} \mathrm{I}$ and ${ }^{137} \mathrm{Cs}$, they derived pre-Chernobyl inventory of $26 \mathrm{mBq} \mathrm{m}^{-2}$ and $2.4 \mathrm{kBq} \mathrm{m}^{-2}$ for ${ }^{129} \mathrm{I}$ and ${ }^{137} \mathrm{Cs}$, respectively. They noted that the ${ }^{129} \mathrm{I}^{137} \mathrm{Cs}$ ratio can only be explained if there is an additional source of ${ }^{129} \mathrm{I}$ in Belarus except the atmospheric weapons fallout. Their value is well within the range of data observed in our work.

The pre-Chernobyl inventory measured or estimated for Eastern Europe are different from those measured in Western Europe at locations far away from the reprocessing plants. Lower Saxony just had minor fallout from the Chernobyl accident and thus should also be suitable to estimate the preChernobyl fallout of ${ }^{129}$ I. However, we found for Lower Saxony ${ }^{129}$ I deposition densities with a geometric mean and standard deviation of $168 \mathrm{mBq} \mathrm{m}^{-2} \times 1.5^{ \pm 1}$ (Ernst et al., 2003), much higher than in Moscow or Zhitomir. This is due to the fact that in Lower Saxony there is a continuous and ongoing fallout of ${ }^{129} \mathrm{I}$ due to the releases from Sellafield and La Hague reaching values up to $\sim 20$ $\mathrm{mBq} \mathrm{m} \mathrm{m}^{-2} \mathrm{a}^{-1}$ via precipitation at the end of the 1990s (Szidat et al., 2000b; Michel et al., 2002b, 2003). ${ }^{129} \mathrm{I}$ fallout increased from $0.014 \mathrm{mBq} \mathrm{m}^{-2} \mathrm{a}^{-1}$ in 1950 to $\sim 0.8 \mathrm{mBq} \mathrm{m}^{-2} \mathrm{a}^{-1}$ in $1984 / 1985$ in Switzerland (Wagner et al., 1996). From $1997-2000$ the annual deposition of ${ }^{129}$ I in Lower Saxony ranged between 2 and $19 \mathrm{mBq} \mathrm{m} \mathrm{m}^{-2}$. There are no data available, which allow judging how important this fallout is for Poland, Belarus, Ukraine, and Russia. Also, there is no evidence to judge the importance of releases from Russian reprocessing plants. Thus, at the moment we are urged to use the estimates from Moscow and Zhitomir.

The disadvantage of the earlier estimates is that they do not account for the uncertainty of the preChernobyl inventory. The uncertainty $u\left(D_{\text {pre-Ch. }}\left({ }^{129} \mathrm{I}\right)\right)$ finally decides about the capability to distinguish between pre-Chernobyl fallout and that due to the accident. The decision threshold $D_{129}^{*}$ which decides whether a measured inventory $D\left({ }^{129} \mathrm{I}\right)$ exceeds that of the pre-Chernobyl fallout is according to ISO 11929-7 (ISO, 2003) given by 


$$
D_{129}^{*}=k_{1-\alpha} \cdot \sqrt{2} \cdot u\left(D_{\text {pre-Ch. }}\left({ }^{129} \mathrm{I}\right)\right)
$$

$u\left(D_{\text {pre-Ch }}\left({ }^{129} \mathrm{I}\right)\right)$ is the standard uncertainty of $D_{\text {pre-Ch. }}\left({ }^{129} \mathrm{I}\right)$ according to the ISO Guide for the Expression of Uncertainty in Measurements (ISO, 1995). Thus, the question of whether a retrospective dosimetry is feasible depends on how accurately the pre-Chernobyl fallout can be determined.

For the probability of the error of $1^{\text {st }}$ kind $\alpha=0.05$ one obtains $k_{1-\alpha}=1.65$ and with $\left.u\left(D_{\text {pre-Ch}} .{ }^{129} \mathrm{I}\right)\right)$ $=24 \mathrm{mBq} \mathrm{m}^{-2}$ a decision threshold $D_{129}^{*}=56 \mathrm{mBq} \mathrm{m}^{-2}$ for the net inventory of ${ }^{129} \mathrm{I}$ due to the Chernobyl fallout $\left.\left(D\left({ }^{129} \mathrm{I}\right)-D_{\text {pre-Ch. }}{ }^{129} \mathrm{I}\right)\right)$. Only if measured ${ }^{129} \mathrm{I}$ inventories exceed $100 \mathrm{mBq} \mathrm{m}{ }^{-2}\left(=D_{\text {pre- }}\right.$ Ch. $\left.\left({ }^{129} \mathrm{I}\right)+D_{129}^{*}\right)$ one cannot conclude that they are due to fallout from the Chernobyl accident. This leads us to the conclusion that only in contamination zones III and II ${ }^{129}$ I from the Chernobyl accident can be seen (Fig. 6). Moreover, the data obtained for zones III and II have to be corrected for the pre-Chernobyl fallout of $44 \mathrm{mBq} \mathrm{m}^{-2}$.

\subsection{Inventories of ${ }^{129}$ I due to the Chernobyl accident}

The measured total inventories of ${ }^{129} \mathrm{I}$ are plotted against those of ${ }^{137} \mathrm{Cs}$ in Fig. 6. For comparison, we included the data reported by Mironov et al. (2002) and from Straume et al. (1996) for soils from Belarus. In addition, the logarithmic means and standard deviations of ${ }^{129} \mathrm{I}$ and ${ }^{137} \mathrm{Cs}$ total inventories from 7 depth profiles from Lower Saxony/Germany (Ernst et al., 2003) are shown.

The data by Straume et al. (1996) and by Mironov et al. (2002) exhibit the same trends as ours. Moreover, they fill a gap in our data set for total ${ }^{137} \mathrm{Cs}$ inventories between $10 \mathrm{kBq} \mathrm{m}^{-2}$ and $200 \mathrm{kBq}$ $\mathrm{m}^{-2}$ where a number of samples appears to be significantly affected by the ${ }^{129} \mathrm{I}$ fallout from the Chernobyl accident. The large variation of the ${ }^{129}$ I data together with the likewise extreme variability of the total ${ }^{129}$ I inventories for ${ }^{137} \mathrm{Cs}$ integral deposition densities above $1 \mathrm{MBq} \mathrm{m}{ }^{-2}$ observed by 
them and Straume et al. (1996) demonstrates clearly that a retrospective dosimetry of the ${ }^{131} \mathrm{I}$ exposure via ${ }^{137} \mathrm{Cs}$ is not meaningful.

This is well in line with the actual differences between total ${ }^{131} \mathrm{I}$ and the ${ }^{137} \mathrm{Cs}$ inventories which occurred due to time-dependent elemental fractionation during emission and atmospheric transport. UNSCEAR (2000) reported values between 10 and 30 for this ratio and Talerko (2004) calculated ratios of ${ }^{131} \mathrm{I}$ and ${ }^{137} \mathrm{I}$ inventories between 5 and 28 for Ukraine taking into account the detailed emission history and the actual weather conditions.

Also Hou et al. (2003) investigated ${ }^{129} \mathrm{I}$ and ${ }^{137} \mathrm{Cs}$ in 11 soils from Belarus and Russia. Their data are fairly consistent with ours for ${ }^{137} \mathrm{Cs}$ inventories exceeding $100 \mathrm{kBq} \mathrm{m}{ }^{-2}$. But, there is a problem

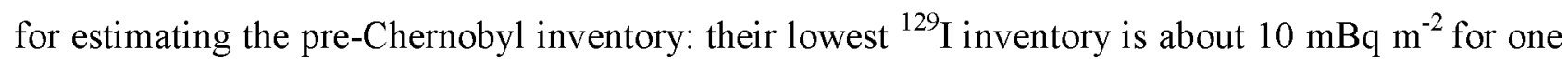
sample with a ${ }^{137} \mathrm{Cs}$ inventory of only $0.91 \mathrm{kBq} \mathrm{m}^{-2}$. The latter value is unreasonably low since the fallout of the nuclear weapons tests is about $5 \mathrm{kBq} \mathrm{m}^{-2}$.

Fig. 6 emphasizes the geographical variability of the $D_{\text {pre-Ch. }}\left({ }^{129} \mathrm{I}\right)$ if one compares the data from Lower Saxony with those measured in soils from Russia and Ukraine. Consequently, it is a conditio sine qua non for the retrospective dosimetry via ${ }^{129} \mathrm{I}$ to derive reliable data and an uncertainty estimate for $D_{\text {pre-Ch. }}\left({ }^{129} \mathrm{I}\right)$. From Fig. 6 , one also observes that the $D_{\text {pre-Ch. }}\left({ }^{137} \mathrm{Cs}\right)$ of $\left(4.8 \times 1.4^{ \pm 1}\right) \mathrm{kBq} \mathrm{m}{ }^{-2}$ derived for Lower Saxony/Germany (Ernst et al., 2003) is also a good estimate for the preChernobyl integral ${ }^{137} \mathrm{Cs}$ inventory in Ukraine, Belarus and Russia as it is to be expected from the homogeneity of the global weapons fallout.

In contamination zones II and III, the ${ }^{129}$ I inventroies are significantly higher than those from Moscow and Zhitomir and allow estimation of the contribution from the Chernobyl fallout by correcting the radionuclide data for the pre-Chernobyl fallout. There remains the general tendency of the ${ }^{129} \mathrm{I}$ 
inventories to increase with the ${ }^{137} \mathrm{Cs}$ inventories, but the large variability of the ${ }^{129}$ I inventory for a given one of ${ }^{137} \mathrm{Cs}$ prohibits substituting ${ }^{129} \mathrm{I}$ by ${ }^{137} \mathrm{Cs}$ for the purpose of retrospective dosimetry. This is due to the differentiation between ${ }^{137} \mathrm{Cs}$ and ${ }^{129} \mathrm{I}$ during the atmospheric dispersion and the fact that the districts of Korosten und Narodici received the fallout not from the first plume which went north affecting in particular Belarus, where Straume et al. (1996) observed the up to now highest ${ }^{129}$ I inventories.

Also, the individual villages in zones II and III investigated in this work show considerable variations of the total inventories both for ${ }^{129} \mathrm{I}$ (table 3) and ${ }^{137} \mathrm{Cs}$ (Handl et al., 2003). In order to account for the large variability of the total ${ }^{129}$ I inventories, we have calculated the expectation values of the total inventories for each village assuming a logarithmic normal distribution of the total inventories. With an arithmetic mean $\mu$ and a standard deviation $\sigma$ of the natural logarithms of the total inventories, the expectation value $\mathrm{E}\left(D\left({ }^{129} \mathrm{I}\right)\right)$ is given by

$$
\mathrm{E}\left(D\left({ }^{129} \mathrm{I}\right)\right)=\exp \left(\mu+\sigma^{2} / 2\right)
$$

With the expectation values of the total ${ }^{129}$ I inventories those of ${ }^{131}$ I were calculated in order to derive dose estimates for the people living in these villages. However, the ${ }^{131} \mathrm{I}^{129} \mathrm{I}$ activity ratio at the time of the accident has to be discussed first.

\subsection{The ${ }^{131} \mathrm{I}^{129} \mathrm{I}$ activity ratio}

There are several estimates of the ${ }^{129} \mathrm{I} /{ }^{131} \mathrm{I}$ isotopic ratio at the time of the accident (table 4). Straume et al. (1996) estimated the ${ }^{129} \mathrm{I}^{131} \mathrm{I}$ isotopic ratio on the basis of ${ }^{129} \mathrm{I}$ measurements of four aliquots of one soil sample from Gomel for which an ${ }^{131} \mathrm{I}$ measurements was available and obtained ${ }^{129} \mathrm{I} /{ }^{131} \mathrm{I}$ $=12 \pm 3$; individual values ranged from $10-14$. This isotopic ratio is equivalent to an activity ratio 
${ }^{131} \mathrm{I} /{ }^{129} \mathrm{I}$ of $5.9 \times 10^{7}$. Mironov et al. (2002) used the same method and obtained ${ }^{129} \mathrm{I} /{ }^{131} \mathrm{I}=15.2 \pm 4.7$ from the analysis of 24 soil samples. VanMiddlesworth and Handl (1997) investigated animal thyroid glands and obtained ${ }^{129} \mathrm{I} /{ }^{131} \mathrm{I}=27 \pm 10$, the individual values ranging from 18.6 to 89.3 . Szidat et al. (2000c) analyzed sewage sludge and found ${ }^{129} \mathrm{I}^{131} \mathrm{I}=34 \pm 2.8$ From the analysis of rain samples from Israel and from Munich, Germany a weighted mean of ${ }^{129} \mathrm{I}^{131} \mathrm{I}=19 \pm 5$ was obtained, the individual samples ranging from 9 to 35 (Paul et al., 1987; Kutschera et al., 1988). Also the results of burn-up calculations are conflicting. Kirchner and Noack (1988) estimated ${ }^{129} \mathrm{I}^{131} \mathrm{I}=22.8$, while Ermilov et al. (1993) estimated a range between 11 and 15 for ${ }^{129} \mathrm{I}^{131} \mathrm{I}$.

There are different sources of uncertainties in the various estimates. One is related to the operational history of the reactor and to the accuracy achievable by burn-up calculations. A second one is that the amount of pre-Chernobyl ${ }^{129}$ I which might be in an environmental sample is not known. A third one is that large corrections for decay of ${ }^{131} \mathrm{I}$ during the long time-spans of the emission and postemission phases affect the accuracy of the ratio determinations; see Talerko (2004) for a detailed discussion.

The first source of uncertainties affects the results of Ermilov (1993) and of Kirchner and Noack (1988) which are highly discrepant. The rain samples (Paul et al., 1987; Kutschera et al., 1988), the sewage sludge (Szidat et al., 2000c), and the animal thyroids VanMiddlesworth and Handl (1996) are likely to be affected by uncertainty sources numbers two and three. The ${ }^{129} \mathrm{I} /{ }^{127} \mathrm{I}$ isotopic ratios in bovine thyroid glands from Austria and in deer thyroid glands from Bavaria/Germany sampled in May/June 1986 clearly represent a peak due to the Chernobyl accident over the long-term trend of iodine isotopic ratios in Western Europe (Michel et al., 2000). Given, however, the uncertainties of the arrival of the radioactive cloud, of the efficiency of the transfer of fallout iodine into the thyroids, and of the potential addition to the Chernobyl ${ }^{129}$ I from the accident of other anthropogenic ${ }^{129} \mathrm{I}$, the resulting ${ }^{129} \mathrm{I} /{ }^{131} \mathrm{I}$ atomic ratios are likely to be highly overestimated. 
We, therefore, prefer the estimates based on the soil samples from Belarus. They are not affected by theoretical considerations. Belarus was the first country to receive the fresh fallout and together with other Eastern European states is less affected by pre-Chernobyl fallout. If the pre-Chernobyl fallout is small then the smallest ${ }^{129} \mathrm{I}^{131} \mathrm{I}$ isotopic ratio should have the highest credibility. The mean isotopic ratio calculated from the work of Straume et al. (1986) and of Mironov et al. (2002) is ${ }^{129} \mathrm{I} /{ }^{131} \mathrm{I}=13.6 \pm 2.8$, which we assume here as the best estimate.

On the basis of the total ${ }^{129} \mathrm{I}$ inventories corrected for the pre-Chernobyl fallout of $44 \mathrm{mBq} \mathrm{m}^{-2}$, the total ${ }^{131} \mathrm{I}$ inventories were calculated using an initial isotopic ratio ${ }^{129} \mathrm{~V} /{ }^{131} \mathrm{I}$ of the Chernobyl fallout of $13.6 \pm 2.8$ equivalent to an activity ratio $A_{131} / A_{129}=(5.3 \pm 0.3) \cdot 10^{7}$. The expectation values of the total ${ }^{131}$ I inventories for the villages investigated in this work are given in table 4 .

\subsection{The aggregated dose coefficients for ${ }^{131} I$ exposure}

The retrospective dosimetry of ${ }^{131} \mathrm{I}$ exposures via ${ }^{129} \mathrm{I}$ needs aggregated dose coefficients for ${ }^{131} \mathrm{I}$ in units of $\mathrm{Sv}$ per $\mathrm{Bq} \mathrm{m}^{-2}$ to convert the total ${ }^{131} \mathrm{I}$ inventory (derived from total ${ }^{129} \mathrm{I}$ inventories) into estimates of ${ }^{131} \mathrm{I}$ thyroid equivalent doses and consequently depends on the reliability of radioecological modeling.

Robl et al. (1997) used the ECOSYS model (Müller and Pröhl, 1993) to calculate the inhaled and ingested ${ }^{131}$ I activities depending on the particular weather conditions during fallout. These authors emphasized that the main uncertainty in the model calculations depends on whether the fallout occurred via wet or dry deposition. The fact that the fallout in Northern Ukraine was mainly due to dry deposition (Talerko, 2004) makes this a minor problem. But, unfortunately, aggregated dose coefficients cannot be derived from the work of Robl et al. (1997). 
Up to now, Pietrzak-Flis et al. (2003) were the only authors reporting actual ${ }^{131}$ I dose estimates on the basis of a retrospective dosimetry using ${ }^{129} \mathrm{I}$. They used the CLRP model (Krajewski, 1996) in the form of a computer code by Krajewski (1999) to derive the required dose coefficients. From the data given in their publication aggregated dose coefficients can be derived for 3 age groups. According to their model calculations, the dose coefficients for the committed thyroid equivalent doses are $(2.5 \pm 0.1) \times 10^{-7} \mathrm{~Sv} \mathrm{~Bq}^{-1} \mathrm{~m}^{2}$ for 5-year-old children, $(1.7 \pm 0.1) \times 10^{-7} \mathrm{~Sv} \mathrm{~Bq}^{-1} \mathrm{~m}^{2}$ for 10-yearold children, and $(5.9 \pm 0.3) \times 10^{-8} \mathrm{~Sv} \mathrm{~Bq}^{-1} \mathrm{~m}^{2}$ for adults. We shall use them to give first order estimates of the thyroid doses in the Korosten and Narodici districts based on our integral ${ }^{129}$ I deposition densities.

It is to note, that these dose coefficients are much lower than those calculated by the German "Allgemeine Berechnungsgrundlage" (BMI, 1979) and the "Störfall-Berechnungsgrundlage" (BMI, 1977): $1.3 \cdot 10^{-6} \mathrm{~Sv} \mathrm{~Bq}^{-1} \mathrm{~m}^{2}$ for a one-year-old child and $0.22 \cdot 10^{-6} \mathrm{~Sv} \mathrm{~Bq}^{-1} \mathrm{~m}^{2}$ for an adult. These latter models are used in Germany for planning purposes and are known to give highly conservative results. The differences in the aggregated dose coefficients are, however, mainly due to differing model assumptions and only to a minor degree due to the differences between the differences in older (BMU, 1989) or newer ICRP dose coefficients which are part of the European Basic Safety Standards (CEC, 1996).

For more detailed dose estimates, fallout calculations taking into account the actual weather conditions in April and May 1986 have to be combined with realistic radioecological model calculations. Such calculations have not yet been performed. Calculations of the actual fallout fields were recently performed by Talerko (2004), but a radioecological modeling of the transfer from fallout to man considering the actual ecological conditions at the time of the accident is still missing. It is also beyond the scope of this publication. 


\subsection{Exposure due to ${ }^{131} I$ in villages of the Korosten and Narodici districts}

In table 5, we present the results for the thyroid exposures based on the aggregated dose coefficients deduced from the work of Pietrzak-Flis et al. (2003). We did not apply a time correction for the decay of ${ }^{131}$ I from the reactor to the districts of Korosten and Narodici. There is official evidence that the radioactive cloud arrived already on April 27, 1986 at Narodici and that the ambient dose rate fell quickly after April 28, 1986.

According to our calculations, thyroid exposures due to ${ }^{131} \mathrm{I}$ of the order of $10 \mathrm{~Sv}$ have to be assumed for the children living in 1986 close to Narodici where no countermeasures were undertaken at that time and where the population was not even warned to stay at home or to avoid drinking milk or eating fresh vegetables and salad. For adults the thyroid exposure was about $3 \mathrm{~Sv}$. Also in the vicinity of Korosten thyroid doses of more than $1 \mathrm{~Sv}$ for children and of nearly $0.4 \mathrm{~Sv}$ for adults must be assumed.

All these dose estimates are in the range of thyroid doses (between $0.3 \mathrm{~Sv}$ und $40 \mathrm{~Sv}$ ) derived from measurements of children aged up to 7 from Gomel in Belarus (NEA, 1995). The estimates are also compatible with the thyroid exposures of children from Belarus reported by UNSCEAR (2000) and are well within the range of individual thyroid dose measurements in Northern Ukraine (Goulko et al., 1998). Typically, the latter individual doses show in each age group a high variability with ranges of an order of magnitude or more. These ranges are well in line with the observed differences in ${ }^{129}$ I deposition densities with geometric standard deviations of the order of two. This variability calls for a probabilistic approach when calculating more refined dose coefficients for the

retrospective dosimetry of ${ }^{131} \mathrm{I}$ exposure using ${ }^{129} \mathrm{I}$. Presently, our data in table 5 just estimate the expectation value of the distribution of the individual thyroid doses. 
Up to now, ${ }^{137} \mathrm{Cs}$ was used more often to reconstruct the thyroid exposure to ${ }^{131} \mathrm{I}$ than ${ }^{129} \mathrm{I}$. Kruk et al. (2004) summarized the respective earlier work and performed new model calculations for Belarus. They considered the actual weather and ecological conditions at the time of the accident and as far as available - information about the fallout ratio of ${ }^{131} \mathrm{I}$ and ${ }^{137} \mathrm{Cs}$. We used their results for aggregated dose coefficients for villages in Northern Ukraine where more than 10 measurements of the ${ }^{131} \mathrm{I}$ and ${ }^{137} \mathrm{Cs}$ fallout were available $\left(3.6 \times 10^{-6} \mathrm{~Sv}\right.$ per $\mathrm{Bq} \mathrm{m}^{-2}$ for 5 -year-old children, $2.3 \times 10^{-6}$ $\mathrm{Sv}$ per $\mathrm{Bq} \mathrm{m}{ }^{-2}$ for 10 -year-old children, and $1.5 \times 10^{-6} \mathrm{~Sv}$ per $\mathrm{Bq} \mathrm{m}^{-2}$ for adults) to convert ${ }^{137} \mathrm{Cs}$ deposition densities to thyroid doses. The thyroid doses calculated in this way agree with our estimates based on ${ }^{129} \mathrm{I}$ within a factor of two for adults and within $30 \%$ for 5 -years-old children. However, there remains the caveat that this agreement crucially depends on the knowledge of the ratio of the actual ${ }^{131} \mathrm{I}$ and ${ }^{137} \mathrm{Cs}$ fallout.

Thus, a retrospective assessment of the ${ }^{131} \mathrm{I}$ exposure via ${ }^{129} \mathrm{I}$ in soils appears feasible though the uncertainties of the derived doses are surely large. Surely direct measurements of the thyroids after the accident have to be preferred if available. For areas, however, where such measurements were lacking, retrospective dosimetry via ${ }^{129} \mathrm{I}$ will be a valuable tool to assess the consequences of the accident.

\section{Conclusions}

After a nuclear accident, such as the Chernobyl catastrophe, the long-lived ${ }^{129} \mathrm{I}$ in soils can be used to determine in retrospect the exposure of the thyroid to ${ }^{131} \mathrm{I}$. In the case of the Chernobyl accident, this is, however, only feasible in areas with high ${ }^{129}$ I inventories which statistically significantly exceed the pre-accident depositions from nuclear atmospheric weapons tests and from the emissions from European reprocessing plants. There remain large uncertainties for the thyroid dose estimates via ${ }^{129}$ I which are connected with still open questions about the migration of iodine isotopes in soils, 
about the initial ${ }^{131} \mathrm{I} /{ }^{129} \mathrm{I}$ activity ratio, and about the aggregated ${ }^{131} \mathrm{I}$ dose coefficients. In spite of these open questions, which deserve further investigations, retrospective dosimetry via ${ }^{129}$ I can yield valuable information on the radiation exposure due to ${ }^{131} \mathrm{I}$ in areas where no direct measurements of thyroids exist, in particular, since ${ }^{137} \mathrm{Cs}$ cannot be used for this purpose.

\section{Acknowledgements}

The valuable assistance by M. Gorny (ZSR, University Hannover) in the RNAA and in the sample preparation for AMS is gratefully acknowledged. Neutron irradiations were performed at the research reactor of the GKSS, Geesthacht, Germany. This work was supported by the Deutsche Forschungsgemeinschaft (DFG).

\section{References}

BMI, German Federal Ministry for the Interior. Rahmenempfehlungen für den Katastrophenschutz in der Umgebung kerntechnischer Anlagen (Störfallberechnungsgrundlage) vom Oktober 1977. GMB1 1977.

BMI, German Federal Ministry for the Interior. Allgemeine Berechnungsgrundlage für die Bestimmung der Strahlenexposition bei radioaktiven Ableitungen mit der Abluft oder in Oberflächengewässer. (Richtlinie zu § 45 StrSchV). GMB1 1979.

BMU. Federal Ministry for the Environment, Nature Conservation and Reactor Safety, Bekanntmachung der Dosisfaktoren, Äußere Exposition - Erwachsene und Kleinkinder (1 Jahr); Ingestion und Inhalation Erwachsene und Kleinkinder. Bonn 05.09.1989, Bundsanzeiger 1989; 41 No. 185a: $29-677$.

BNFL, British Nuclear Fuel. Annual Report on Discharges and Monitoring of the Environment 1998. Risley 1999

Botsch W, Romantschuk LD, Handl J, Beltz D, Michel R. Experimental investigations on the radiation exposure of inhabitants of contaminated areas in Northern Ukraine. Proceedings IRPA10, Hiroshima, May 14-19, 2000, CD 2000 P-11-254.

Botsch W. Untersuchungen zur Strahlenexposition von Einwohnern der nördlichen Ukraine. PhD thesis. University Hannover 2000.

Carter MW, Moghissi AA. Three decades of nuclear testing. Health Physics 1977; 33: 55 - 71. 
CEC. Council Directive 96/29/Euratom of 13 May 1996 laying down basic safety standards for the protection of the health of workers and the general public against the dangers arising from ionizing radiation, OJ 1-159 of 29.06.1996 page 1.

Chamberlain AC. Radioactive Aerosols. Cambridge University Press 1991.

Eisenbud M, Gesell T. Environmental Radioactivity, $4^{\text {th }}$ ed., Academic Press, San Diego 1997, 556 ff.

England, TR, Rider BF. ENDF-349 evaluation and compilation of fission product yields. Rep. LAUR-94-3106, 1994.

Ermilov AP, Makarenkova II, Melekhin YuA. Research of neutron activation measurements of iodine in biological samples applying to the problem of the Chernobyl iodine reconstruction. Medeleievo, Moscow Region: All-Russian Scientific Institute of Physical-Technical and Radiotechnical Measurements 1993, in Russian.

Ernst T, Szidat S, Handl J, Jakob D, Michel R, Schnabel C, Synal H-A, Santos Arevalo FJ, Benne I, Boess J, Böttcher J, Gehrt E, Capelle A, Schneider J, Schäfer W. ${ }^{129}$ I und ${ }^{127}$ I in europäischen Böden, in: Michel R, Täschner M, Bayer A (eds). Praxis des Strahlenschutzes: - Messen, Modellieren, Dokumentieren -, Tagungsband der 34. Jahrestagung des Fachverbandes für Strahlenschutz e.V., Kloster Seeon, 21. 25. April 2002, TÜV-Verlag, Köln 2002; 167 - 174.

Ernst T, Szidat S, Handl J, Jakob D, Michel R, Schnabel C, Synal H-A, Santos Arevalo FJ, Benne I, Boess J, Gehrt E, Capelle A, Schneider J, Schäfer W, Böttcher J. Migration of iodine129 and iodine-127 in soils. Kerntechnik 2003; 68: 155 - 167.

Filss M, Botsch W, Handl J, Michel R. A fast method for the determination of strontium-89 and strontium-90 in environmental samples and its application to the analysis of strontium-90 in Ukrainian soils. Radiochim Acta 1998; 83: 81 - 92.

Finkel RC, Suter M. AMS in the Earth Sciences: Technique and Applications, Advances in Analytical Geochemistry 1993; 1: 1- 114.

Goulko GM, Chepurny NI, Jacob P, Kairo IA, Likhtarev IA, Pröhl G, Sobolev BG. Thyroid dose and throid cancer incidence after the Chernobyl accident: assessments for the Zhytomyr region (Ukraine). Radiat Environ Biophys 1998; 36: 216-273.

Gray J, Jones SR, Smith AD. Discharges to the environment from the Sellafield Site, 1951 - 1992. J Radiol Prot 1995; 15: 99 - 131.

Groupe Radioécologie Nord-Cotentin, c/o Institut de Protection et de Sûreté Nucléaire, Inventaire des rejets radioactifs des installations nucléaires, Volume 1: Historique des rejets. Fontenayaux-Roses 1999 (in French).

Handl J, Beltz D, Botsch W, Harb S, Jakob D, Beltz D, Michel R, Romantschuk LD. Fallout and transfer into the human food chain of cesium-137 and the radiation exposure of inhabitants of contaminated areas in Northern Ukraine. Health Physics 2003; 84: 502 - 517.

Hou XL, Fogh CL, Kucera J, Andersson KG, Dahlgard H, Nielsen SP. Iodine-129 and Caesium137 in Chernobyl contaminated soil and their chemical fractionation. The Science of the Total Environment 2003; 308: 97 - 109. 
ISO Guide to the Expression of Uncertainty in Measurement. ISO International Organization for Standardization, Geneva 1993, corrected reprint 1995.

ISO/FDIS 11929-7, Determination of detection limit and decision threshold for ionizing radiation measurements. Part 7: Fundamentals and general applications, ISO, Geneva 2003.

Kirchner G, Noack CC. Core history and nuclide inventory of the Chernobyl core at the time of the accident. Nuclear Safety 1988; 29: $1-5$.

Krajewski P. CLRP version 4.2 MANUAL, BIOMOVS II Technical Report No 7. Uncertainty and validation effect of user interpretation on uncertainty estimates. Stockholm: BIOMOVS Steering Committee; 1996.

Krajewski P. Evaluation and verification of dose assessment model for radioiodine and radiocaesium environmental releases. Dissertation, Warsaw 1999 (in Polish).

Kruk JE, Pröhl G, Kenigsberg JI. A radioecological model for the thyroid dose reconstruction of the population of Belarus after the Chernobyl accident, to be published (2004).

Kutschera W, Fink D, Paul M, Hollos G, Kaufman A. Measurement of ${ }^{129} \mathrm{I} /{ }^{131} \mathrm{I}$ ratio in the Chernobyl fallout. Physica Scripta 1988; 37: 310-313.

Law of Ukraine No. 796-XII: On the Status and Social Protection of Citizens, who have Suffered as a Consequence of the Chernobyl Catastrophe, VVR 191, No. 16 p. 220, 28.2.1991.

Mewis A. Strontium-90 in der Umwelt: Migrationsverhalten im Boden, Transfer in die Nahrungskette und Strahlenexposition in der nördlichen Ukraine, Ph.D. thesis, University of Hanover, 2004 (in German).

Michel R, Szidat S, Handl J, Jakob D, Synal H-A, Suter M. Status and trends of iodine-129 abundances in the European environment. Proceedings IRPA10, Hiroshima, May 14 - 19, 2000. CD. 2000 P-4a-229.

Michel R, Handl J, Ernst T, Botsch W, Szidat S, Schmidt A, Jakob D, Beltz D, Romantschuk LD, Synal H-A, Schnabel C, López-Gutiérrez JM. Fallout and migration of iodine-129 in contaminated areas of Northern Ukraine (extended abstract). Int. Conf. Radioactivity in the Environment, Monaco, September 1-5, 2002a (CD ROM).

Michel R, Ernst T, Szidat S, Schnabel C, Synal H-A. Iodine-129 as a long-lived tracer in the environment. Proc. Int. Conf. on the Study of Environmental Change using Isotope Techniques. 23.27.4.2001, IAEA, Vienna, IAEA-CSP 13/P, IAEA, Vienna, 2002b, pp. 336 - 345.

Michel R, Ernst T, Jakob D, Szidat S, Synal H-A, Schnabel C. Long-lived radionuclides in the environment: The case of iodine-129. Proceedings EUROSAFE, Berlin 2002, November 4 - 5, Berlin, 2002c. http://www.eurosafe-forum.org/ipsn/pdf/euro2_4_2_iodine129.pdf

Michel R, Ernst T, Szidat S, Schnabel C, Synal H-A. Langfristige Entwicklung von Iod-129 in der Umwelt, Proc. Klausurtagung des Radioökologieausschusses der SSK 2003, in press.

Mironov V, Kudriaschov V, Krivomas M, Drugatschenok M, Schmura G, Yiou F, Raisbek G, Gall $\mathrm{P}$. Application of ${ }^{129} \mathrm{I}$ as indicator for the reconstruction of the ${ }^{131} \mathrm{I}$ content in human thyroid glands as a consequence of the Chernobyl accident. ed. IRB-2, Belarussian Academy of Scinece, Institute for Radiobiology, Minsk 1999 (in Russian). 
Mironov V, Kudrjashov V, Yiou F, Raisbeck GM. Use of ${ }^{129} \mathrm{I}$ and ${ }^{137} \mathrm{Cs}$ in soils fort he estimation of ${ }^{131} \mathrm{I}$ deposition in Belarus as a result of the Chernobyl accident. J Environm Radioactivity 2002; 59: $293-307$.

Moran JE, Fehn U, Teng RTD. Variations in ${ }^{129} \mathrm{I} /{ }^{127} \mathrm{I}$ ratios in recent marine sediments: evidence for a fossil organic component, Chemical Geology 1998;152: 193 - 203.

Moran JE, Oktay S, Santschi PH, Schink DR. Atmopsheric dispersal of ${ }^{129}$ I from nuclear reprocessing facilities, Environ Sci Technol 1999; 33: 2536 - 2542.

Müller H, Pröhl G. ECOSYS-87: A dynamic model for assessing radiological consequences of nuclear accidents. Health Physics 1993; 63: 232 - 252.

Nuclear Energy Agency. Chernobyl - ten years. On radiological and health impact; An Assessment by the NEA Committee on Radiation Protection and Public Health, Paris, November 1995.

Oktay SD, Santschi PH, Moran JE, Sharma P. The Iodine-129 bomb pulse recorded in Mississippi River Delta Sediments: results from isotopes of I, $\mathrm{Pu}, \mathrm{Cs}, \mathrm{Pb}$ and C. Geochim Cosmochim Acta 2000; 64: $989-996$.

Paul M, Fink D, Hollos G, Kaufman A, Kutschera W, Magaritz M. Measurement of ${ }^{129}$ I concentrations in the environment after the Chernobyl reactor accident: Nucl Instr Meth Phys Res 1987; B 29: $341-345$.

Parker T (BNFL). priv. comm. with C. Schnabel, May 11, 2001.

Pietrzak-Flis Z, Krajewski P, Radwan I, Muramatsu Y. Retrospective evaluation of ${ }^{131}$ I deposition density and thyroid dose in Poland after the Chernobyl accident. Health Physics 2003, 84: 698 $-708$

Raisbeck GM, Yiou F, Zhou ZQ, Kilius LR. ${ }^{129}$ I from nuclear fuel reprocessing facilities at Sellafield (U.K.) and La Hague (France); potential as an oceanographic tracer. J Mar Sys 1995; 6: $561-570$.

Raisbeck GM, Yiou F, Eymas C, Lestringuez J. The new heavy ion line at Gif-sur-Yvette AMS facility. Nucl Instr Meth Phys Res 2000; 172: $170-176$.

Rao U., Fehn U. Sources and Reservoirs of Anthropogenic Iodine-129 in Western New York, Geochim Cosmochim Acta 1999; 63: 1927 - 1938.

Reithmeier H, Lazarev V, Rühm W, Blinov A, Huber T, Kubo F, Nolte E. ${ }^{131}$ I dose reconstruction in the former Soviet-Union (FSU) by measurement of ${ }^{129} \mathrm{I}$. Annual Report 2001, Beschleunigerlaboratorium der Universität und Technischen Universität München. 2002: 25.

Roberts ML, Caffee MW, Proctor ID. ${ }^{129}$ I interlaboratory comparison. Nucl Instr Meth Phys Res 1997; B 123: 367 - 370

Roberts ML, Caffee MW, ${ }^{129}$ I interlaboratory comparison: Phase II results. Nucl Instr Meth Phys res 2000; B172: $388-394$.

Robl R, Voigt G, Paretzke HG. Rekonstruktion der Schilddrüsendosis für Kinder mit Schilddrüsenkrebs in Weissrussland. GSF-Bericht 24/97 1997 (in German) 
Schink DR, Santschi PH, Corapcioglu O, Fehn U. Prospects for "iodine-129 dating" of marine organic matter using AMS, Nucl Instr Meth Phys Res 1995; B99: 524 - 527.

Schmidt A, ${ }^{129}$ I und stabiles Jod in Umweltproben - Qualitätskontrolle von Analysenmethoden und Untersuchungen zur Radioökologie und zur retrospektiven Dosimetrie. Ph.D. thesis, University Hanover 1998.

Schmidt A, Schnabel C, Handl J, Jakob D, Michel R, Synal H-A, Lopez JM, Suter M. On the analysis of iodine-129 and iodine-127 in environmental materials by accelerator mass spectrometry and ion chromatography. Sci Total Environ 1998; 223: 131 - 156.

Schnabel C, López-Gutiérrez JM, Szidat S, Sprenger M, Wernli H, Beer J, Synal H-A. On the origin of ${ }^{129} \mathrm{I}$ in rain water near Zurich. Radiochimica Acta 2001; 89: 815 - 822.

Slavov VP, Didukh MI, Borshenko VV, Malarchiuk PM, Michel R, Handl J. Vertical migration of ${ }^{137} \mathrm{Cs}$ and ${ }^{129}$ I Chornobyl's origin in turf-podsol soils of Ukrainian Polissya. News of Agrarian Sciences - Kiiv: Agrarna nauka, 1997, special issue August 1997, 27 - 30 (1999) (in Ukrainian).

Straume T, Marchetti AA, Anspaugh LR, Khrough VT, Gavrilin YI, Shinkarev SM, Drozdovitch VV, Ulanovski AV, Korneev SV, Brekeshev MK, Leonov ES, Voigt G, Pachenko SV, Minenko VF. The feasibility of using ${ }^{129}$ I to reconstruct ${ }^{131}$ I deposition from the Chernobyl reactor accident. Health Physics 1996; 71: 733 - 740

Szidat S, Iod-129: Probenvorbereitung, Qualitätssicherung und Analyse von Umweltmaterialien (in German). Ph.D. thesis, Univ. of Hanover (2000). Available at: http://edok01.tib.unihannover.de/edoks/e002/32217211X.pdf.

Szidat S, Schmidt A, Handl J, Jakob D, Michel R, Synal H-A, Schnabel C, Suter M, LopezGutierrez JM. RNAA and AMS of iodine-129 in environmental materials - comparison of analytical methods and quality assurance -. Kerntechnik 2000a; 65: 160 - 167.

Szidat S, Schmidt A, Handl J, Jakob D, Botsch W, Michel R, Synal H-A, Schnabel C, Suter M, López-Gutiérrez JM, Städe W. Iodine-129: Sample preparation, quality control and analyses of pre-nuclear materials and of natural waters from Lower Saxony, Germany. Nucl Instr Meth Phys Res 2000b; B172: 699 - 710.

Szidat S, Schmidt A, Handl J, Jakob D, Michel R, Synal H-A, Suter M. Analysis of iodine-129 in environmental materials: quality assurance and applications. J. Radioanal. Chem 2000c; 244 : $45-50$.

Talerko N., Reconstruction of ${ }^{131}$ I radioactive contamination in Ukraine caused by the Chernobyl accident using atmospheric transport modelling, Science of the Total Environment (2004) submitted.

UNSCEAR. United Nations Scientific Committee on the Effects of Atomic Radiation reports to the General Assembly of the United Nations. 1982.

UNSCEAR. Report of the United Nations Scientific Committee on the Effects of Atomic Radiation to the General Assembly, ANNEX J Exposures and effects of the Chernobyl accident. 2000.

VanMiddlesworth L, Handl J. ${ }^{129} \mathrm{I},{ }^{131} \mathrm{I}$ and ${ }^{127} \mathrm{I}$ in animal thyroids after the Chernobyl nuclear accident. Health Physics 1997; 73: $647-650$. 
Wagner MJM, Dittrich-Hannen B, Synal H-A, Suter M, Schotterer U. Increase of iodine-129 in the environment. Nucl Instr Meth Phys Res 1996; B113: 490 - 494.

Webmaster Cogema. priv comm with C Schnabel. Feb 1, 2001.

Yiou F, Raisbeck GM, Zhou ZQ, Kilius LR. ${ }^{129}$ I from nuclear fuel reprocessing; potential as an oceanographic tracer. Nucl Instr Meth Phys Res 1994; B92: 436 - 439. 


\section{Table and Figure Captions}

Table 1: $\quad$ Results of RNAA for ${ }^{127} \mathrm{I}$ and ${ }^{129} \mathrm{I}$ in 51 samples of top soils $(\mathrm{d} \leq 10 \mathrm{~cm})$ from various affected and unaffected locations in Ukraine, Belarus, and Russia sampled between September 1991 and October 1992.

Table 2: Total inventories and their associated standard uncertainties of ${ }^{129} \mathrm{I}$ and ${ }^{137} \mathrm{Cs}$ in Moscow and in three different areas of Northern Ukraine. ${ }^{137} \mathrm{Cs}$ data are decay-corrected for April 26, 1986. The entries under "sample type" indicate whether the inventories were determined from measured depth profiles or from average samples.

Table 3: Geometric means and standard deviations of total ${ }^{129}$ I inventories as derived from the analysis of soil profiles from differently contaminated areas.

Table 4: ${ }^{129} \mathrm{I} /{ }^{131} \mathrm{I}$ atomic ratios measured in environmental samples after the Chernobyl accident.

Table 5: Expectation values $\mathrm{E}\left(D_{\text {corr }}(\mathrm{I}-129)\right)$ according to equation 6 of total inventories of ${ }^{129} \mathrm{I}$ measured in zone II and III corrected for global weapons fallout, inferred expectation value of total ${ }^{131} \mathrm{I}$ inventories $\mathrm{E}(D(\mathrm{I}-131))$ and resulting ${ }^{131} \mathrm{I}$ radiation exposures of thyroid glands $H_{\text {thyroid }}$ using the aggregated dose factors $D C_{131}$ accrding to Pietrzak-Fils et al. (2003).

Fig. 1: Map of Northern Ukraine with contamination zones II $\left({ }^{137} \mathrm{Cs}\right.$ deposition density $>555$ $\left.\mathrm{kBq} \mathrm{m}{ }^{-2}\right)$ and III $\left({ }^{137} \mathrm{Cs}\right.$ deposition density $\left.185-555 \mathrm{kBq} \mathrm{m}^{-2}\right)$ and the sampling sites. The circles indicate $30 \mathrm{~km}$ and $60 \mathrm{~km}$ distances from the NPP, respectively. 
Fig. 2: Concentrations in $\mathrm{mg} \mathrm{kg}^{-1}$ (top) and inventories within individual depth increments in $\mathrm{mg} \mathrm{m}^{-2}$ (bottom) of ${ }^{127} \mathrm{I}$ in soil profiles from Moscow, Nemirovka, and Nosdrischtsche.

Fig. 3: Depth profiles of ${ }^{129}$ I specific activities in soils from Moscow (Moscow VI: diamonds; Moscow VII: squares) and Northern Ukraine: zone IV (Lewkow 1: triangles; Lewkow 2: diamonds), zone III (Nemirovka 2: open triangles; Woronewo 4: squares; KupetschTschernjanka 1: diamonds), and zone II (Nosdrischtsche II: diamonds; Christinovka meadow: open circles; Christinovka river shore: squares).

Fig. 4: ${ }^{129} \mathbf{I} /{ }^{127}$ I isotopic ratios in the soil profiles Moscow VI (diamonds), and Moscow VII (squares), Nemirovka II (triangles) and Nosdrischtsche 2 (circles).

Fig. 5: Inventories within individual depth increments of ${ }^{129} \mathrm{I}$ (full symbols) and ${ }^{137} \mathrm{Cs}$ (open symbols) in soils from (top panel) Moscow VI (diamonds), Moscow VII (squares) and from Levkov (circles) and Baraschevka (triangles) in Ukraine; (middle panel) contamination zones III (Tschigiri: full circles; Kupetsch-Tschernjanka: full squares; Woronewo: full diamonds; Nemirovka: full triangles) and (bottom panel) contamination zone II (Christinovka river shore: squares; Christinovka meadow: triangles).

Fig. 6: Total ${ }^{129} \mathrm{I}$ and ${ }^{137} \mathrm{Cs}$ inventories measured from this work (full symbols) in depth profiles from Moscow/Russia (diamonds), Zhitomir region/Ukraine (circles), Korosten region/Ukraine (squares) and Narodici region/Ukraine (triangles). For comparison, the results of the investigations by Straume et al. (1996) (open triangles) for Belarus and by Mironov et al. (2002) for Belarus (open diamonds) and the logarithmic mean and 
standard deviation (cross) obtained for seven soil profiles from Lower Saxony/Germany by Ernst et al. (2003) are given.

Table 1: Results of RNAA for ${ }^{127} \mathrm{I}$ and ${ }^{129} \mathrm{I}$ in 51 samples of top soils $(\mathrm{d} \leq 10 \mathrm{~cm})$ from various affected and unaffected locations in Ukraine, Belarus, and Russia sampled between September 1991 and October 1992.

\begin{tabular}{|l|c|c|c|}
\hline & I-127 & I-129 & $129 / 127$ \\
& in $\mathrm{mg} / \mathrm{kg}$ & in $\mathrm{mBq} / \mathrm{kg}$ & in $10^{-10}$ \\
\hline Geometric mean and standard deviation & $1.9 \times 2.2^{ \pm 1}$ & $3.0 \times 3.3^{ \pm 1}$ & $2700 \times 4.7^{ \pm 1}$ \\
Minimum & 0.29 & 0.05 & 45 \\
Maximum & 8.6 & 111 & 74000 \\
\hline
\end{tabular}


Table 2: Total inventories and their associated standard uncertainties of ${ }^{129} \mathrm{I}$ and ${ }^{137} \mathrm{Cs}$ in Moscow and in three different areas of Northern Ukraine. ${ }^{137} \mathrm{Cs}$ data are decay-corrected for April 26, 1986. The entries under "sample type" indicate whether the inventories were determined from measured depth profiles or from average samples.

\begin{tabular}{|c|c|c|c|c|c|c|}
\hline \multirow{3}{*}{ location } & \multirow{3}{*}{ sample type } & \multirow{3}{*}{$\begin{array}{c}{ }^{129} \mathbf{I} \\
\text { analytical } \\
\text { method }\end{array}$} & \multicolumn{2}{|c|}{${ }^{129} \mathrm{I}$} & \multicolumn{2}{|c|}{${ }^{137} \mathrm{Cs}$} \\
\hline & & & $\mathrm{D}$ & $\mathrm{u}(\mathrm{D})$ & $\mathrm{D}$ & $\mathrm{u}(\mathrm{D})$ \\
\hline & & & \multicolumn{2}{|c|}{ in $\mathrm{mBq} / \mathrm{m}^{2}$} & \multicolumn{2}{|c|}{ in $\mathrm{kBq} / \mathrm{m}^{2}$} \\
\hline Moscow VI 1996 & profile & AMS & 64 & 5 & 4.57 & 0.37 \\
\hline Moscow VII 1996 & profile & AMS & 37 & 3 & 3.63 & 0.29 \\
\hline \multicolumn{7}{|c|}{ not contaminated } \\
\hline Baraschevka 1 & profile & RNAA/AMS & 32.1 & 9.1 & 3.14 & 0.30 \\
\hline Baraschevka 2 & average & AMS & 25.4 & 2.8 & 5.88 & 0.47 \\
\hline Baraschevka 3 & average & AMS & 34.2 & 3.8 & 4.28 & 0.35 \\
\hline Baraschevka 4 & average & AMS & 29.8 & 5.1 & 3.69 & 0.33 \\
\hline Oserjanka 1 & average & AMS & 44.2 & 4.6 & 6.36 & 0.50 \\
\hline Oserjanka 2 & average & AMS & 17.7 & 1.9 & 3.57 & 0.31 \\
\hline Oserjanka 3 & average & AMS & 34.4 & 3.6 & 6.79 & 0.40 \\
\hline \begin{tabular}{|l|} 
Davidovka 1 \\
\end{tabular} & average & AMS & 28.6 & 3.1 & 4.64 & 0.41 \\
\hline Davidovka 2 & average & AMS & 47.4 & 4.9 & 4.32 & 0.40 \\
\hline \begin{tabular}{|l|} 
Levkov 1 \\
\end{tabular} & profile & RNAA/AMS & 81.6 & 8.2 & 5.27 & 0.46 \\
\hline Levkov 2 & profile & RNAA/AMS & 101 & 11 & 6.22 & 0.47 \\
\hline \multicolumn{7}{|c|}{ medium contaminated (zone III) } \\
\hline Nemirovka 2 & profile & RNAA/AMS & 186 & 14 & 492 & 44 \\
\hline Nemirovka 3 & average & AMS & 237 & 25 & 454 & 50 \\
\hline Nemirovka 4 & average & AMS & 74.4 & 7.8 & 394 & 51 \\
\hline Woronewo 1 & average & AMS & 195 & 32 & 527 & 54 \\
\hline Woronewo 2 & average & AMS & 116 & 12 & 375 & 41 \\
\hline Woronewo 3 & average & AMS & 172 & 31 & 356 & 84 \\
\hline Woronewo 4 & profile & RNAA/AMS & 218 & 24 & 851 & 110 \\
\hline Woronewo 5 & average & AMS & 175 & 19 & 612 & 60 \\
\hline Woronewo 6 & average & AMS & 181 & 19 & 598 & 55 \\
\hline Woronewo 7 & average & AMS & 85.7 & 9.2 & 296 & 19 \\
\hline Kupetsch-Tschernjanka 1 & profile & RNAA/AMS & 197. & 19 & 332 & 31 \\
\hline Kupetsch-Tschernjanka 2 & average & AMS & 100 & 11 & 277 & 21 \\
\hline Tschigiri 1 & profile & RNAA/AMS & 300 & 29 & 320 & 37 \\
\hline Tschigiri 2 & average & AMS & 78.8 & 8.1 & 338 & 34 \\
\hline Tschigiri 3 & profile & RNAA/AMS & 138 & 16 & 397 & 41 \\
\hline Tschigiri Zwintor 1 & average & AMS & 88.2 & 8.0 & 356 & 43 \\
\hline Tschigiri Zwintor 2 & average & AMS & 168 & 15 & 237 & 23 \\
\hline Tschigiri Zwintor 3 & average & AMS & 97.0 & 8.8 & 528 & 52 \\
\hline Tschigiri Rjet. Most 2 & average & AMS & 81.5 & 8.4 & 350 & 38 \\
\hline Tschigiri Rjet. Most 3 & average & AMS & 139 & 14 & 556 & 51 \\
\hline Tschigiri Ferma 1 & average & AMS & 105 & 11 & 381 & 36 \\
\hline Tschigiri Ferma 2 & average & AMS & 72.7 & 7.5 & 360 & 39 \\
\hline Tschigiri Chmilnik 1 & average & AMS & 111 & 11 & 532 & 52 \\
\hline Tschigiri Chmilnik 2 & average & AMS & 95.6 & 9.9 & 442 & 39 \\
\hline \multicolumn{7}{|c|}{ highly contaminated (zone II) } \\
\hline Nosdrischtsche 2 & profile & AMS & 1390 & 100 & 5229 & 327 \\
\hline Nostrischtsche 3 & average & AMS & 653 & 71 & 2587 & 1382 \\
\hline Novo Scharno 2 & average & AMS & 974 & 97 & 3318 & 237 \\
\hline Novo Scharno 3 & average & AMS & 811 & 80 & 3479 & 276 \\
\hline Novo Scharno 4 & average & AMS & 1212 & 120 & 3916 & 457 \\
\hline Christinovka river shore & profile & RNAA/AMS & 1098 & 122 & 4218 & 436 \\
\hline Christinovka meadow & profile & RNAA/AMS & 388 & 44 & 738 & 50 \\
\hline
\end{tabular}


Table 3: Geometric means and geometric standard deviations of total ${ }^{129}$ I inventories as derived from the analysis of soil profiles from differently contaminated areas.

\begin{tabular}{|c|c|c|c|c|}
\hline $\begin{array}{c}\text { location and } \\
\text { year of sampling }\end{array}$ & $\begin{array}{c}\text { number } \\
\text { of } \\
\text { profiles }\end{array}$ & $\begin{array}{l}\text { depth of } \\
\text { profiles } \\
\text { in } \mathrm{cm}\end{array}$ & $\begin{array}{c}\text { total }{ }^{129} \mathrm{I} \\
\text { inventory } \\
\text { in } \mathrm{mBq} \mathrm{m}{ }^{-2}\end{array}$ & reference \\
\hline \multicolumn{5}{|c|}{ pre-nuclear } \\
\hline Lutovinovo, Russia, 1939 & 1 & 35 & $0.084 \pm 0.017$ & Szidat et al. (2000b) \\
\hline \multicolumn{5}{|c|}{ not contaminated by fall-out from Chernobyl } \\
\hline Moscow, Russia, 1996 & 2 & 40 & $49 \times 1.5^{ \pm 1}$ & this \\
\hline Zhitomir, Ukraine, 1997 & 12 & 40 & $38 \times 1.7^{ \pm 1}$ & this \\
\hline Lower Saxony, D, 1999 & 7 & 250 & $168 \times 1.5^{ \pm 1}$ & Ernst et al. (2003) \\
\hline \multicolumn{5}{|c|}{ contamination zones in Ukraine } \\
\hline mean, zone III, 1995 & 24 & 40 & $130 \times 1.5^{ \pm 1}$ & this \\
\hline Nemirovka, 1995 & 3 & 40 & $94 \times 2.1^{ \pm 1}$ & this \\
\hline Woronewo, 1995 & 7 & 40 & $109 \times 1.7^{ \pm 1}$ & this \\
\hline Kupetsch-Tschernjanka, 1995 & 2 & 40 & $93 \times 2.0^{ \pm 1}$ & this \\
\hline Tschigiri, 1995 & 12 & 40 & $67 \times 1.9^{ \pm 1}$ & this \\
\hline mean, zone II, 1995 & 7 & 40 & $848 \times 1.5^{ \pm 1}$ & this \\
\hline Nosdrischtsche, 1995 & 2 & 40 & $905 \times 1.8^{ \pm 1}$ & this \\
\hline Novo Scharno, 1995 & 3 & 40 & $941 \times 1.2^{ \pm 1}$ & this \\
\hline Christinovka, 1995 & 2 & 40 & $602 \times 2.2^{ \pm 1}$ & this \\
\hline
\end{tabular}


Table 4: ${ }^{129} \mathrm{I} /{ }^{131}$ I atomic ratios measured in environmental samples after the Chernobyl accident. The ${ }^{131}$ I data are given for April 26, 1986.

\begin{tabular}{|c|c|c|c|c|}
\hline material & origin & sampling date & $\begin{array}{l}{ }^{129} I^{131} I \\
\text { atomic } \\
\text { ratio }^{\text {a) }}\end{array}$ & reference \\
\hline sewage sludge & Berlin/D & May 1986 & $34.3 \pm 2.8$ & this work \\
\hline $\begin{array}{l}\text { bovine and deer } \\
\text { thyroid glands }\end{array}$ & $\begin{array}{l}\text { Ulm/D, Bad } \\
\text { Hall/A }\end{array}$ & $\begin{array}{l}\text { May - June } \\
1986\end{array}$ & $27 \pm 10$ & $\begin{array}{l}\text { VanMiddlesworth and Handl } \\
\text { (1997) }\end{array}$ \\
\hline rain & Munich/D & $\begin{array}{l}\text { end of April } \\
\qquad 1986\end{array}$ & $19 \pm 5$ & Kutschera et al. (1988) \\
\hline rain & Israel & 5. May 1986 & $15 \pm 3$ & Paul et al. (1987) \\
\hline soil & Belarus & $\begin{array}{l}\text { May - June } \\
\quad 1986\end{array}$ & $15 \pm 5$ & Mironov et al. (2002) \\
\hline soil & Belarus & May 1986 & $12 \pm 3$ & Straume et al. (1996) \\
\hline theoretical estimate & - & - & $11-15$ & Ermilov (1993) \\
\hline theoretical estimate & - & - & 22.8 & Kirchner and Noack (1988) \\
\hline
\end{tabular}

${ }^{a)}{ }^{131}$ I concentrations are decay-corrected for April 26, 1986. 
Table 5: Expectation values $\mathrm{E}\left(D_{\text {corr }}(\mathrm{I}-129)\right)$ according to equation 6 of total inventories of ${ }^{129} \mathrm{I}$ measured in zone II and III corrected for global weapons fallout, inferred expectation value of total

${ }^{131}$ I inventories $\mathrm{E}(D(\mathrm{I}-131))$ and resulting ${ }^{131} \mathrm{I}$ radiation exposures of thyroid glands $H_{\text {thyroid }}$ using the aggregated dose factors $D C_{131}$ accrding to Pietrzak-Fils et al. (2003).

\begin{tabular}{|l|c|c|c|c|c|}
\hline & $\begin{array}{c}\mathrm{E}\left(D_{\text {corr }}(\mathrm{I}-129)\right) \\
\text { in } \\
\text { Bq }{ }^{-2}\end{array}$ & $\begin{array}{c}\mathrm{E}(D(\mathrm{I}-131)) \\
10^{6} \mathrm{~Bq} \mathrm{~m}^{-2}\end{array}$ & \multicolumn{4}{|c|}{ 5-year-old } & 10-years-old & adult \\
\hline \multicolumn{5}{|c|}{ medium contaminated area (zone III) close to Korosten } \\
\hline Nemirovka & 0.122 & 6.41 & 1.6 & 1.1 & 0.38 \\
\hline Woronewo & 0.124 & 6.50 & 1.6 & 1.1 & 0.38 \\
\hline Kupetsch & 0.119 & 6.25 & 1.5 & 1.0 & 0.37 \\
\hline Tschigiri & 0.078 & 4.10 & 1.0 & 0.7 & 0.24 \\
\hline & highly contaminated area (zone II) close to Naroditschi & \\
\hline Nosdrischtsche & 1.060 & 55.7 & 14 & 9.3 & 3.3 \\
\hline Novo Scharno & 0.962 & 50.5 & 13 & 8.4 & 3.0 \\
\hline Christinovka & 0.824 & 43.3 & 11 & 7.2 & 2.6 \\
\hline
\end{tabular}




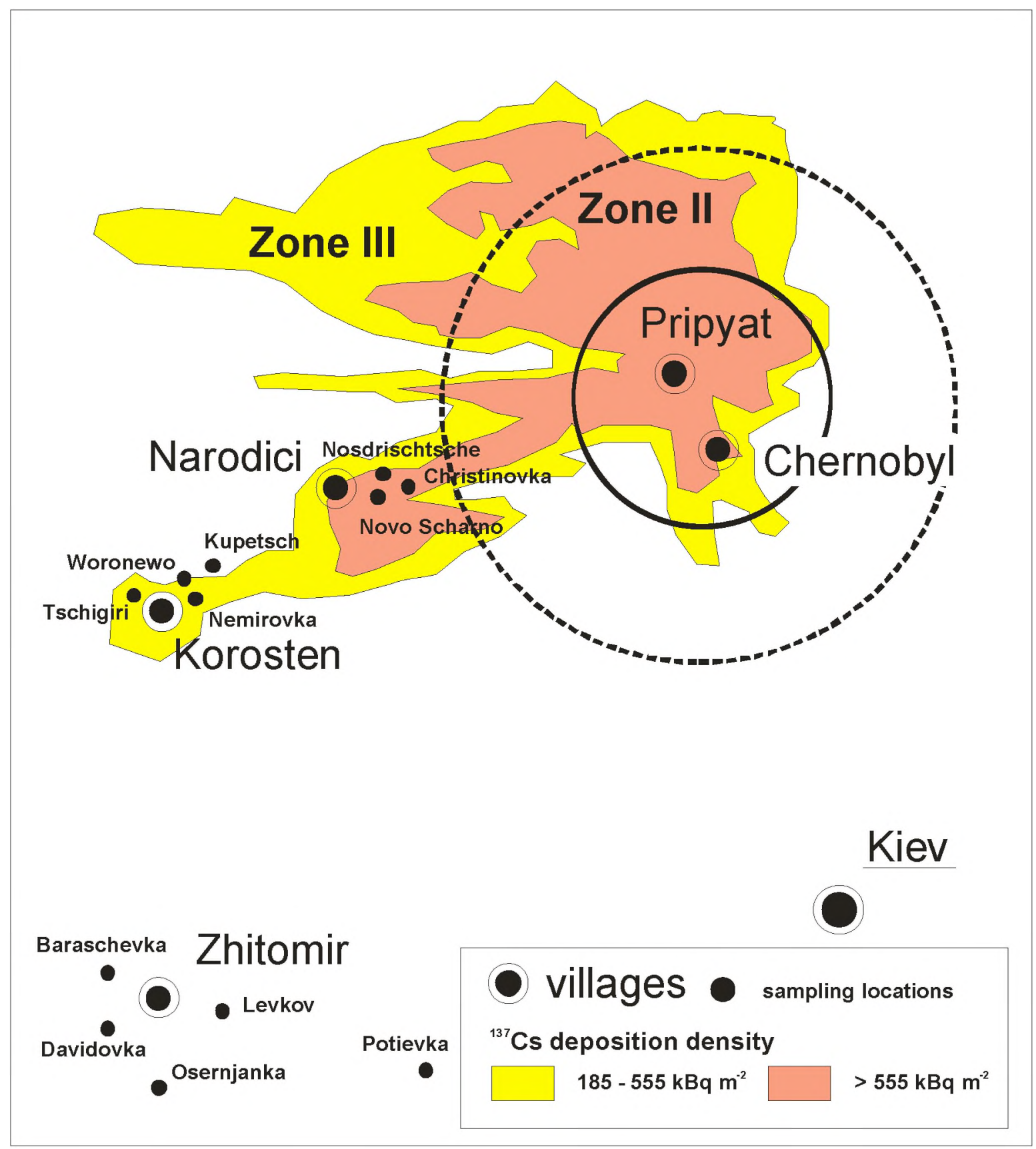

Fig. 1: Map of Northern Ukraine with contamination zones II $\left({ }^{137} \mathrm{Cs}\right.$ deposition density $>555$ $\mathrm{kBq} \mathrm{m}^{-2}$ ) and III ( ${ }^{137} \mathrm{Cs}$ deposition density $\left.185-555 \mathrm{kBq} \mathrm{m}^{-2}\right)$ and the sampling sites. The circles indicate $30 \mathrm{~km}$ and $60 \mathrm{~km}$ distances from the NPP, respectively. 

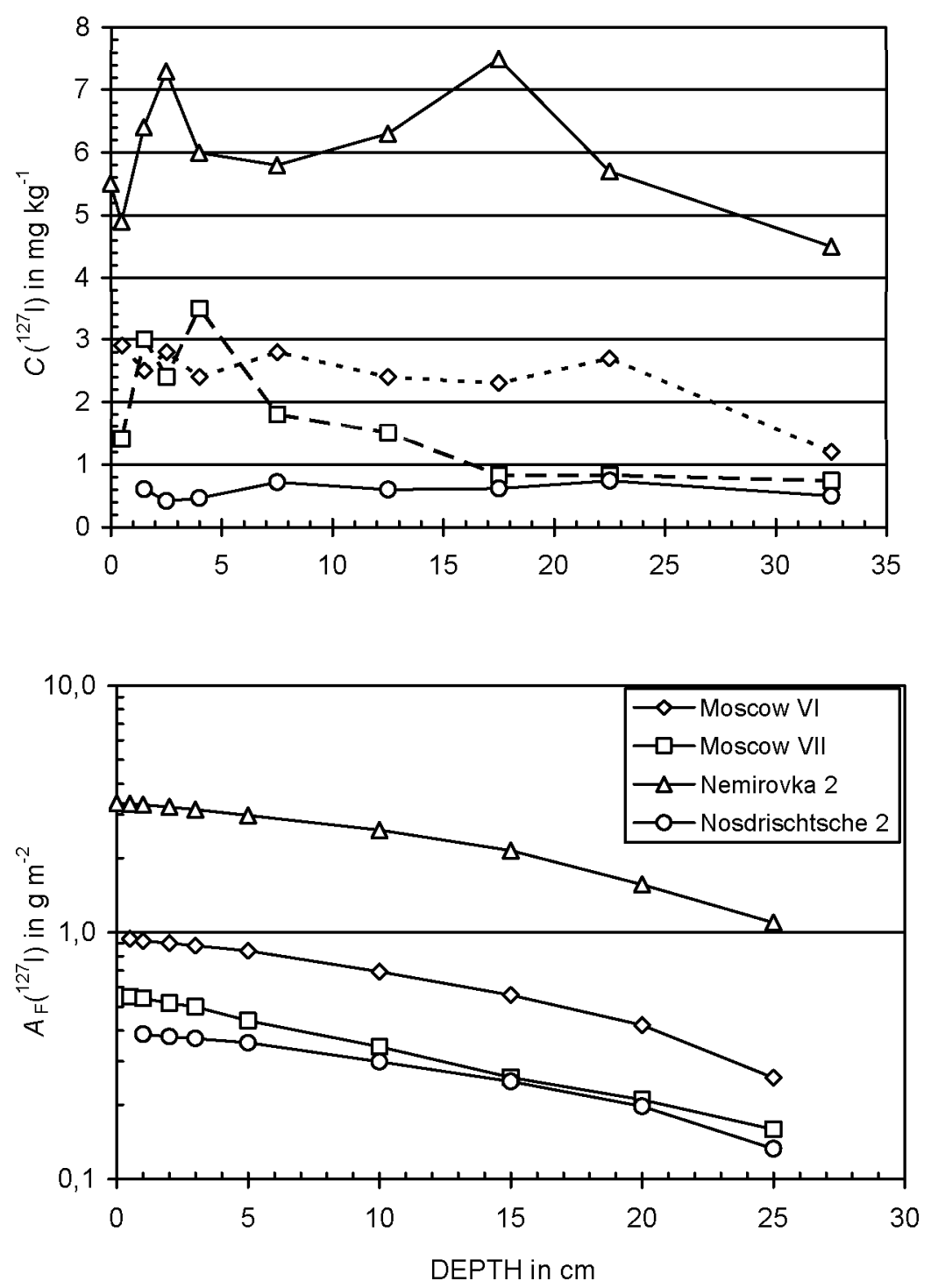

Fig. 2: Concentrations in $\mathrm{mg} \mathrm{kg}^{-1}$ (top) and inventories within individual depth increments in $\mathrm{mg} \mathrm{m}^{-2}$ (bottom) of ${ }^{127} \mathrm{I}$ in soil profiles from Moscow, Nemirovka, and Nosdrischtsche. 

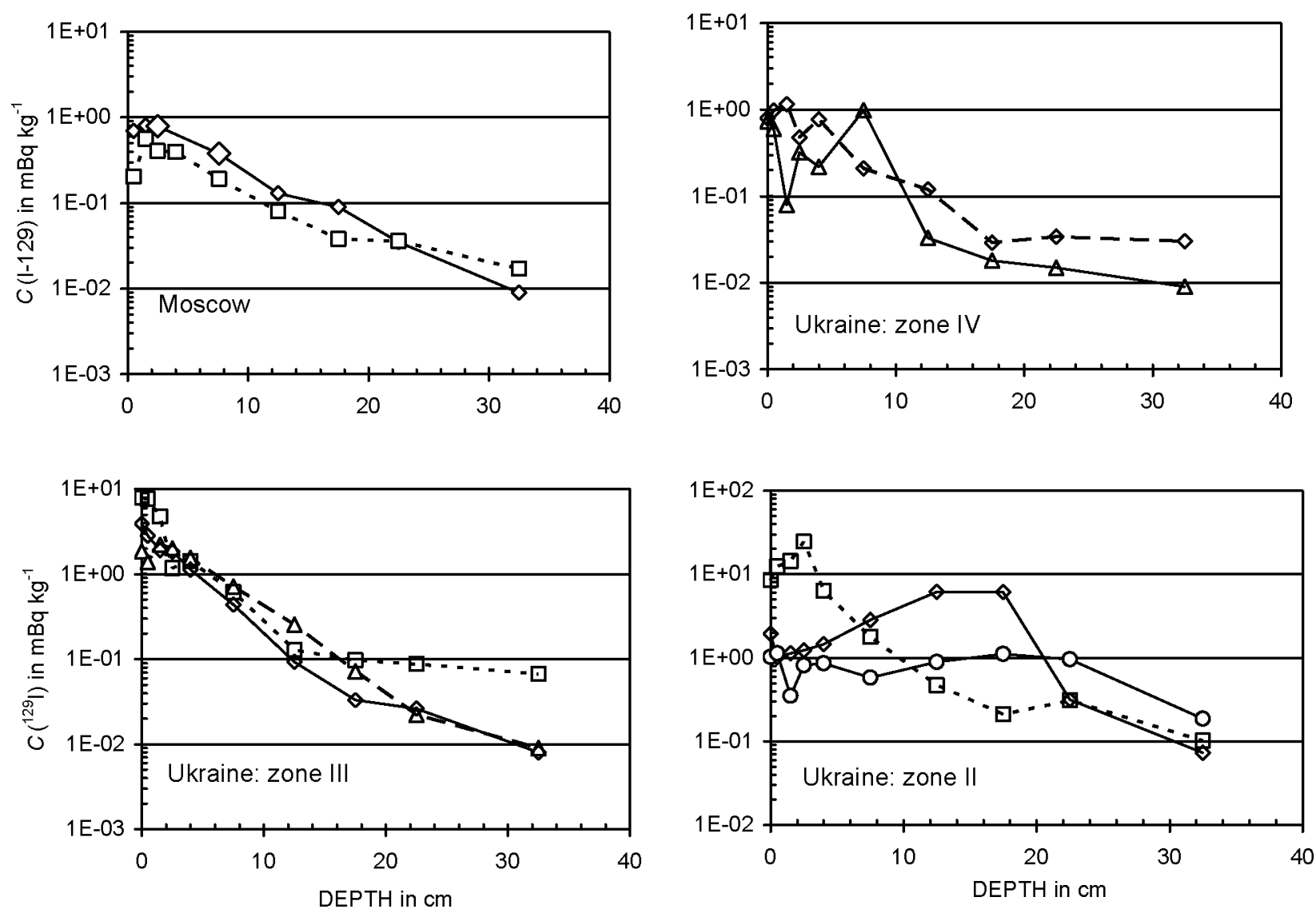

Fig. 3: Depth profiles of ${ }^{129}$ I specific activities in soils from Moscow (Moscow VI: diamonds; Moscow VII: squares) and Northern Ukraine: zone IV (Levkov 1: triangles; Levkov 2: diamonds), zone III (Nemirovka 2: open triangles; Woronewo 4: squares; Kupetsch-Tschernjanka 1: diamonds), and zone II (Nosdrischtsche II: diamonds; Christinovka meadow: open circles; Christinovka river shore: squares). 


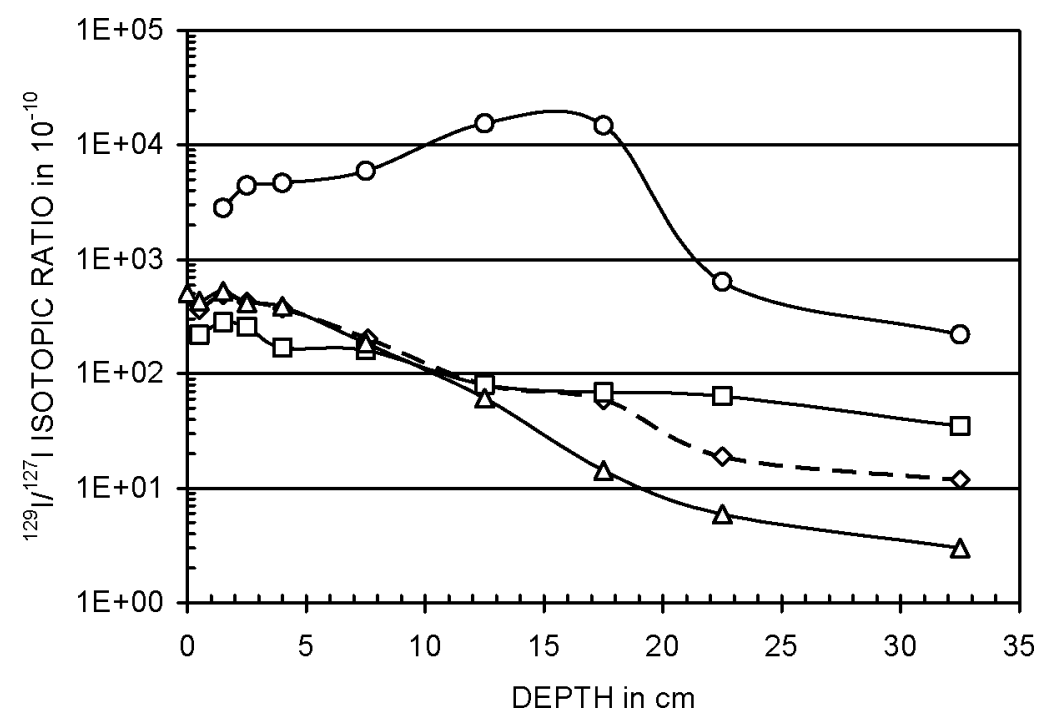

Fig. 4: ${ }^{129} \mathrm{I}^{127} \mathrm{I}$ isotopic ratios in the soil profiles Moscow VI (diamonds), and Moscow VII (squares), Nemirovka II (triangles) and Nosdrischtsche 2 (circles) 

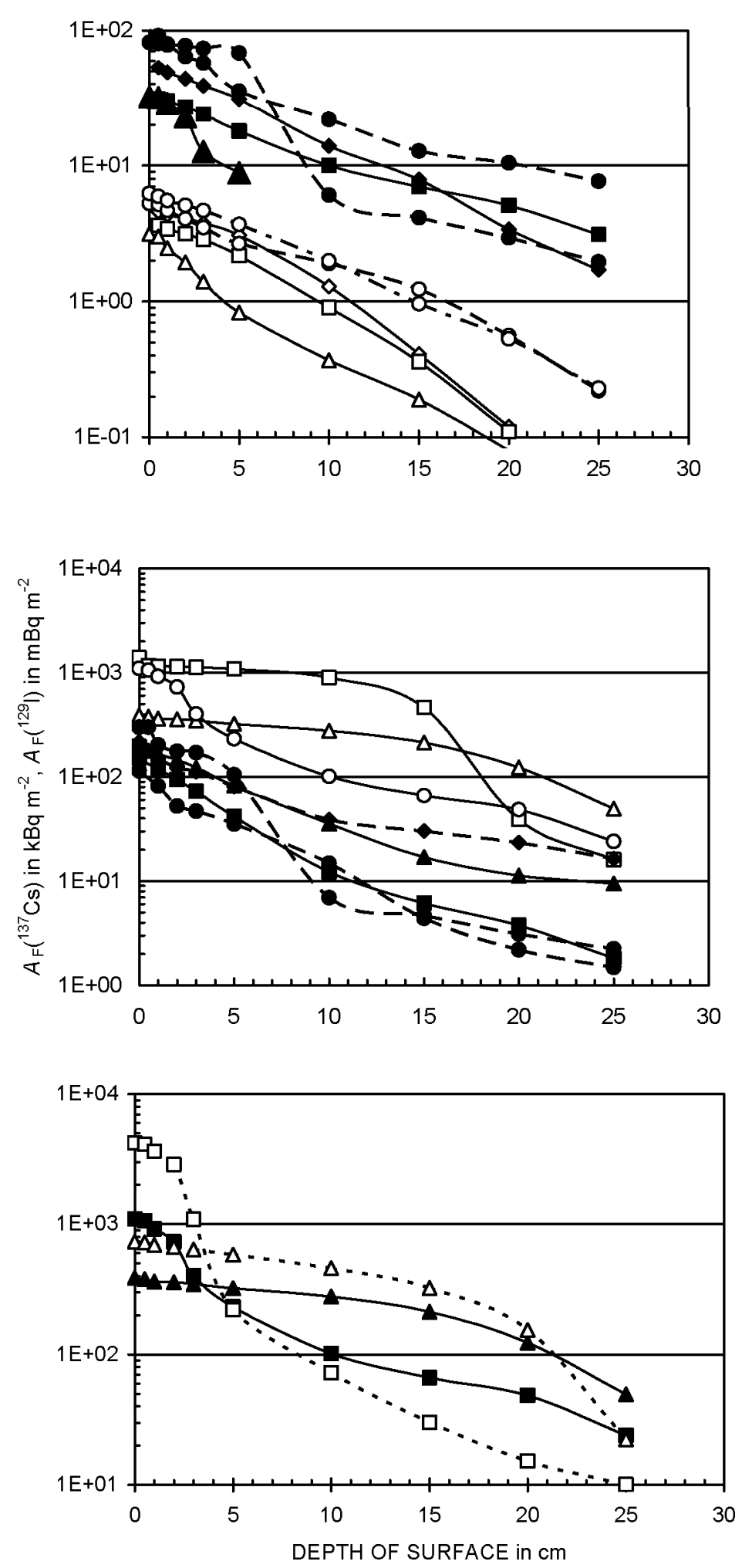

Fig. 5: Inventories within individual depth increments of ${ }^{129} \mathrm{I}$ (full symbols) and ${ }^{137} \mathrm{Cs}$ (open symbols) in soils from (top panel) Moscow VI (diamonds), Moscow VII (squares) and from Levkov (circles) and Baraschevka (triangles) in Ukraine; (middle panel) contamination zones III (Tschigiri: full circles; Kupetsch-Tschernjanka: full squares; Woronewo: full diamonds; Nemirovka: full triangles) and (bottom panel) contamination zone II (Christinovka river shore: squares; Christinovka meadow: triangles). 


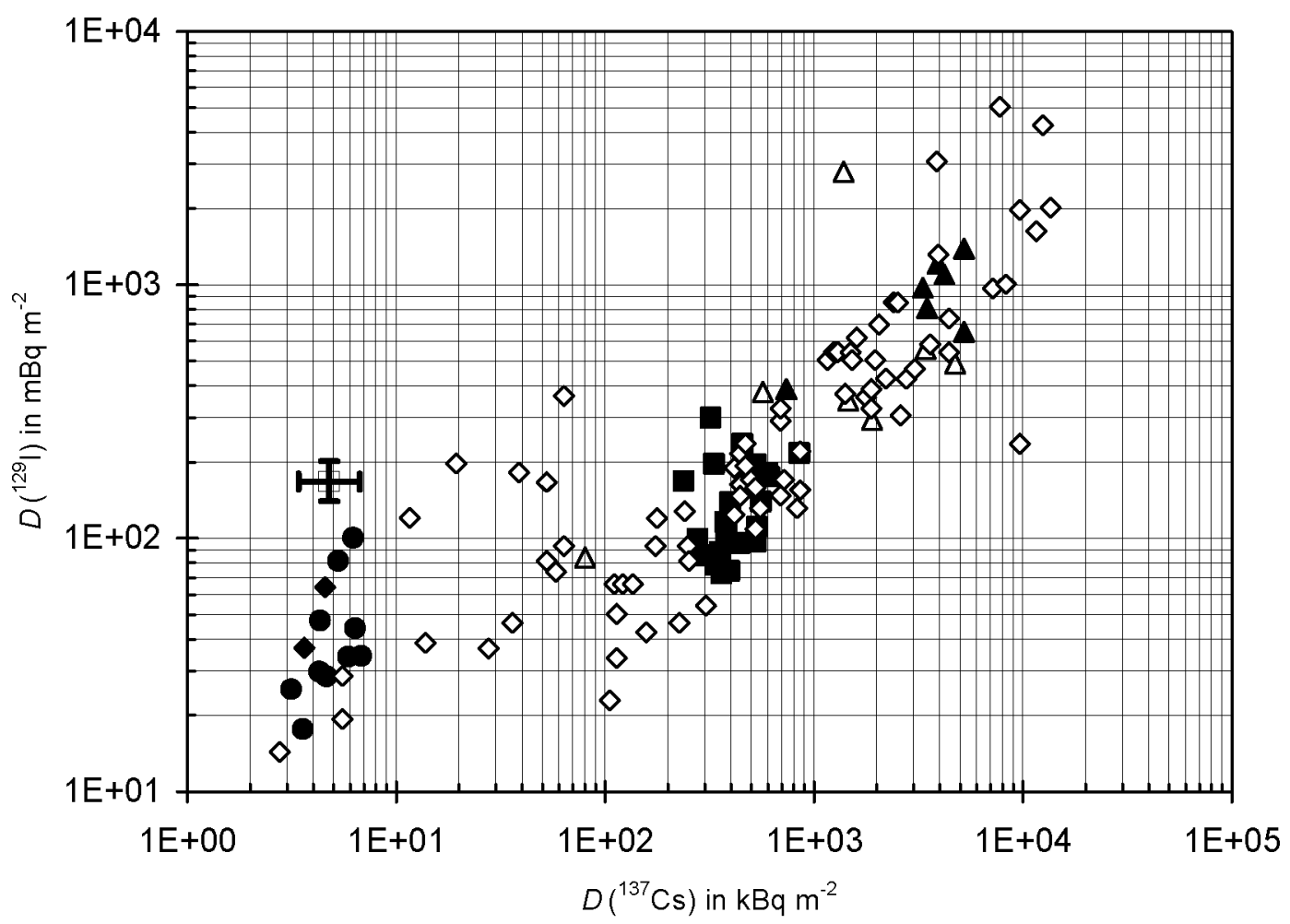

Fig. 6: Total ${ }^{129} \mathrm{I}$ and ${ }^{137} \mathrm{Cs}$ inventories from this work (full symbols) measured in depth profiles from Moscow/Russia (diamonds), Zhitomir region/Ukraine (circles), Korosten region/Ukraine (squares) and Narodici region/Ukraine (triangles). For comparison, the results of the investigations by Straume et al. (1996) (open triangles) for Belarus and by Mironov et al. (2002) for Belarus (open diamonds) and the geometric means and geometric standard deviations (cross) obtained for seven soil profiles from Lower Saxony/Germany by Ernst et al. (2003) are given. 